\title{
Map of the existing research on business innovation, funding, and policy framework
}

\section{Edmund Mallinguh ${ }^{1}\left(\mathrm{D}\right.$, Zeman Zoltan ${ }^{2}$}

\begin{abstract}
In the last decade, empirical studies focusing on business-related innovation, funding of innovation activities, and policy (implications) have continued to increase. However, not enough effort has been undertaken yet to investigate existing literature on the subject matter. To fill the gap, the present study seeks to synthesize and map out existing empirical studies on business innovation, financing, and policy framework published between 1990 and February 2019. Bibliographic analysis of relevant articles retrieved from the Web of Science Core Collection was performed using Vosviewer. The bibliometric results show the prominent publication outlets, authoritative scholars and items, dominant higher learning institutions, and countries. Still, selected articles were content analyzed, providing a summary of the publications, the methodology adopted, country and period covered. The papers were classified into different themes based on the study focus, thus pinpointing areas that have received more or less scholarly attention. The identified gaps from both bibliographic and content analysis offer future research opportunities in different aspects touching on business innovation, how its financed and related policy issues.
\end{abstract}

Keywords: business innovation, funding, policy framework, bibliometrics, citation analysis, Scientometrics

\section{INTRODUCTION}

Gault (2018), from a general point of view, defines innovation as the implementation of an original or significantly distinct process or product.

1 Edmund Mallinguh, Management and Business Administration, School of Economics and Social Sciences, Szent István Egyetem, Gödöllő, Páter Károly u. 1, 2100, Hungary, e-mail: mallinguh.bwire.edmund@phd.uni-szie.hu (ORCID ID: 00000003-1059-4634), corresponding author.

2 Zeman Zoltan, Ph.D., Management and Business Administration, School of Economics and Social Sciences, Szent István Egyetem, Gödöllő, Páter Károly u. 1, 2100, Hungary. 
A product could be a good or service, whereas a process may entail production or delivery, organizational, and marketing processes. Kahn (2018) expounds further by stating that innovation is a combination of three different conditions; innovation as an outcome, as a process, and innovation as a mindset. Kahn explains that as an outcome, it may include but not limited to; product, process, marketing, business model, supply chain, and organizational innovation. These outcomes of innovation have been researched. For example, product innovation (Hannigan, Seidel, \& Yakis-Douglas, 2018; Wang, Wang, Chang, \& Kang, 2019); process innovation (Aliasghar, Rose, \& Chetty, 2019; Diéguez-Soto, Garrido-Moreno, \& Manzaneque, 2018; Möldner, Garza-Reyes, \& Kumar, 2018); marketing innovation (Aksoy, 2017; Fiore, Silvestri, Contò, \& Pellegrini, 2017; Gupta, Malhotra, Czinkota, \& Foroudi, 2016); business model innovation (Ciulli \& Kolk, 2019; Hamelink \& Opdenakker, 2019); supply chain innovation (Chen, Dimitrov, \& Pun, 2018; Sabri, Micheli, \& Nuur, 2018); and organizational innovation (Anzola-Román, Bayona-Sáez, \& García-Marco, 2018; Azar \& Ciabuschi, 2017). Competitiveness and sustainable development in the current highly competitive business environment is achievable through innovation (Pelikánová, 2020). Also, small and medium enterprises must take stock of factors that influence their competitiveness in international markets (Stawasz, 2019)

The framework governing innovation remains critical for any economy, whether emerging or mature, as it can either stifle or stir outcomes, and should never static. Borrás and Laatsit (2019) examined the system-oriented innovation policy focusing on the European Union 28 member states and finds that despite the many positives, there are obstacles with the system that need attention. Policies on innovation are crossing cutting, for instance, Arundel, Bloch, and Ferguson (2019) focused on the public sector; Hermans, GeerlingEiff, Potters, and Klerkx (2018) on public-private partnerships; private sector (Lopez-Berzosa \& Gawer, 2014); emerging economies (Fernández-Sastre \& Montalvo-Quizhpi, 2019); business survival (Ortiz-Villajos \& Sotoca, 2018). The significance of funding innovation is crucial due to associated benefits and risks. Funding remains a hurdle for most firms keen on engaging intensively in innovative activities. That notwithstanding, the link between innovation and its funding has been scrutinized for varying reasons. Yanbo Wang, Li, and Furman (2017) probed the relationship between the performance of a firm and its innovation activities funded by the government; main funders of food and health innovations in the European Union (Strähle et al., 2016); crowdfunding (Wonglimpiyarat, 2018); hedge funding (Brav, Jiang, Ma, \& Tian, 2018) among other studies. 
Equally, a considerable number of review studies on the subject exist such as indicators of innovation (Dziallas \& Blind, 2018); in the supply chain (Wong \& Ngai, 2019); innovation nature and variety (Edwards-Schachter, 2018); business model (Geissdoerfer, Vladimirova, \& Evans, 2018; Pieroni, McAloone, \& Pigosso, 2019); and innovation in organizations (Hauser, Linos, \& Rogers, 2017). Bibliographic coupling, a technique that uses citation analysis to create a similarity link of articles, is an idea by Kessler (1963). Hass (1974) reviewed the theoretical grounding of bibliographic coupling and its practical usage by following the works of Kessler. One advantage of bibliographic review is the ability to eliminate humanly related biases. Small and Koenig (1977) used the technique in earlier times to perform journal clustering. Over the years, the researcher has continued to use the method to map scientific work in various fields. The technique continues to be improved to make the findings more comprehensive and comprehensible (Garfield, 2001).

Hence based on the above, it is crucial to map out existing literature on innovation, funding, and governance. Therefore, this article aims to; perform a bibliographic review to determine the most critical papers on business innovation, finance, and policy; group these articles based on their main themes; present a summary of each of selected publications; highlight areas of possible future research based on the analysis. The authors anticipate that this review will provide a good starting point for future studies on innovation, funding, and policy since no study has attempted to evaluate current literature. Also, it may be relevant to policymakers charged with formulating the right plans on novelty as well as its funding. The study addresses the issues identified by providing answers to the following questions:

\section{RQ1: What is the co-authorship level per country?}

RQ2: What is the extent of collaborative authorship on innovation between or among institutions of higher learning?

RQ3: What are the main themes of the literature reviewed? What are the influential publications on innovation, funding, and policy from a business perspective, their summary?

To the best knowledge of the authors, the current study is the first to analyze scholarly literature on funding critically, policy framework (as well as their effect) on and business innovation. The study is structured as follows: the next part, part two, is about the methodology and articles reviewed in this study. In section three, the study presents co-authorship from a country- 
specific point of view, scientific publications authored through collaboration between institutions of higher learning, and central themes of the papers examined. Part four is a summary of selected articles. Finally, section five is in the conclusion and possible opportunities for future studies.

\section{MATERIAL AND METHOD}

This study employs bibliographic coupling to map out the current literature on business-related innovation, funding, and policy. Furthermore, authors have applied bibliographic review approaches to present a comprehensive picture of research status in various fields, for example, (Chen, 2011; Chen et al., 2014; Jarneving, 2007; Ferreira, 2018). For this analysis, documents were searched in the Web of Science core collection database. "Innovation," "Policy," (and) "Funding" were the key terms used in the search. The search is limited to the period between 1990 and mid-February, 2019. The key words resulted in 2,845 articles, and so to further scale down the figure, another keyword, "Business," was introduced. The final search query was [ 'innovation' AND/ OR 'policy' AND/OR 'funding' AND 'business']. The publications considered are those with query words in the title only. Additionally, the introduction of the 'business' as part of the query, limited the search specifically to businessfocused publications. The search resulted in 437 papers, as illustrated in Table 1 , and articles per year in Figure 1. The authors used Vosviewer software to perform a bibliographic analysis of the document retrieved. Moreover, the 437 articles assessment for association and linkage aimed at singling out related studies, and this resulted in 310 publications.

Also, the 310 documents were analyzed on co-authorship by country and collaborative articles between institutions of higher learning (Finardi, 2014; Talab, Scholten, \& van Beers, 2018). The 310 articles must have been cited at least once for inclusion in the analysis. The citing criterion resulted in 242 publications, out of which only 183 had an association with each other. These 183 articles were grouped differently depending on their themes, as shown by both Table 2 and Figure 6 . Finally, to identify essential publications, a document must have had a minimum of 20 citations to be considered. Thus, from the remaining 183 papers, 44 papers met the cut, but only 32 articles were related, and these are the ones summarised as illustrated by Table 4 . By use of VosViewer, the authors were able to visually present the network of scientific articles on innovation, its funding, and policies from a business point of view. The clustering of reviewed publications shown in Figure 6. The clustering also allowed for the grouping of reviewed articles under particular themes. Figure 1 is a summary of the methodology applied. 


\begin{tabular}{|l|l|l|}
\hline -Number of articles retained after removal of articles with no association or link \\
\hline
\end{tabular} \mid \begin{tabular}{l|l|l|}
\hline -Number of articles retained after erasing those with no association or link \\
\hline
\end{tabular}

Figure 1. Study sampling process

The reviewed articles were visualized in 13 different clusters depending on their strength of association. From a practical point of view, certain documents would have been placed in more than one group or instead appeared to be not so closely related to the chosen cluster; nevertheless, the authors wish not to manipulate the clustering manually. Likewise, these clusters had different numbers of articles, some having more and other less, but the authors, to the best of their abilities, attempted to find the right theme for each group. Under the analysis of the theme, the authors omitted documents that were in a language other than English, articles with limited access, textbooks, which are non-research work and sections of publications on conference proceedings. Using Vosviewer: Bibliographic coupling and Co-authorship were the basis of analysis with the unit of analysis being documents and countries, while the full counting method was adopted. In summary, the outcome comprised of 242 publications analyzed, 64 clusters, 1413 links, and a total strength standing at 2207.

\section{RESULTS AND DISCUSSION}

\section{Scientometrics}

This section examines reviewed articles under three main headings: 1) coauthoring to determine the level of academic cooperation between countries on the subject matter at an international level; 2) collaboration in conducting 
and publishing scientific work by institutions of higher learning, whether locally, in the region or global angle. Collaboration helps in the sharing or spreading of knowledge, based on the strength of the institution and avoid duplication of research efforts; 3 ) provide a summary of reviewed publications deemed necessary on innovation, funding, and policy business-wise. The retrieved literature was published in various journals and conference proceedings, as typified in Table 1. Most papers were in the journals relating to innovation, business, and entrepreneurship.

\section{Number of publications per journal}

Table 1 epitomizes the different journals and conference proceedings for reviewed articles. The journals are many, but generally, most of them are in the field of innovation, business/entrepreneurship, economics, management, and technology

Table 1. Publication in different journals

\begin{tabular}{|c|c|c|c|}
\hline Journal & $\begin{array}{l}\text { No. of } \\
\text { Articles }\end{array}$ & Journal & $\begin{array}{l}\text { No. of } \\
\text { Articles }\end{array}$ \\
\hline Research Policy & 11 & $\begin{array}{l}\text { Technology in Society } \\
\text { International Journal of } \\
\text { Innovation \& Technology }\end{array}$ & 2 \\
\hline Technovation & 7 & $\begin{array}{l}\text { Management } \\
\text { Transformations in Business \& }\end{array}$ & 2 \\
\hline European Planning Studies & 7 & $\begin{array}{l}\text { Economics } \\
\text { International Journal of }\end{array}$ & 2 \\
\hline $\begin{array}{l}\text { Science \& Public Policy } \\
\text { Journal of Technology }\end{array}$ & 6 & $\begin{array}{l}\text { Technology Management } \\
\text { Journal of Entrepreneurship \& }\end{array}$ & 2 \\
\hline $\begin{array}{l}\text { Transfer } \\
\text { Baltic Journal of Economic }\end{array}$ & 6 & $\begin{array}{l}\text { Public Policy } \\
\text { European Journal of Innovation }\end{array}$ & 2 \\
\hline Studies & 6 & Management & 2 \\
\hline Sustainability & 5 & $\begin{array}{l}\text { Competitiveness Review } \\
\text { Health Research Policy \& }\end{array}$ & 2 \\
\hline $\begin{array}{l}\text { Small Business Economics } \\
\text { Tomsk State University }\end{array}$ & 5 & Systems & 2 \\
\hline $\begin{array}{l}\text { Journal } \\
\text { Technological Forecasting \& }\end{array}$ & 5 & $\begin{array}{l}\text { Energy Policy } \\
\text { Journal of New Economics }\end{array}$ & 2 \\
\hline Social Change & 5 & Association & 2 \\
\hline $\begin{array}{l}\text { Marketing \& Management } \\
\text { of Innovations }\end{array}$ & 4 & Research Evaluation & 2 \\
\hline
\end{tabular}




\begin{tabular}{|c|c|c|c|}
\hline Journal & $\begin{array}{l}\text { No. of } \\
\text { Articles }\end{array}$ & Journal & $\begin{array}{l}\text { No. of } \\
\text { Articles }\end{array}$ \\
\hline & & Entrepreneurship and Regional & \\
\hline Journal of Rural Studies & 4 & Development & 2 \\
\hline \multirow[t]{2}{*}{ Venture Capital } & 3 & Industry and Innovation & 2 \\
\hline & & International Journal of & \\
\hline Scientific Bulletin of Polissa & 3 & Cultural Policy & 2 \\
\hline \multicolumn{4}{|l|}{ Journal of Small Business \& } \\
\hline Enterprise Development & 3 & Climate Policy & 2 \\
\hline \multicolumn{4}{|l|}{ Industry and Higher } \\
\hline Education & 3 & Journal of Economic \& Policy & 2 \\
\hline \multicolumn{4}{|l|}{ Journal of Knowledge- } \\
\hline \multirow[t]{2}{*}{ Economy } & 3 & Terra Economicus & 2 \\
\hline & & $\begin{array}{l}\text { Entrepreneurial Knowledge, } \\
\text { Technology \& the }\end{array}$ & \\
\hline Food Policy & 3 & Transformation of Regions & 2 \\
\hline \multirow[t]{2}{*}{ Health Affairs } & 3 & Policy Studies & 2 \\
\hline & & Economics of Innovation and & \\
\hline Foresight \& STI Governance & 3 & New Technology & 2 \\
\hline BMC International Health & & Economics of Innovation and & \\
\hline and Human Rights & 3 & Technology & 2 \\
\hline \multicolumn{4}{|l|}{$\begin{array}{l}\text { Asia Pacific Journal } \\
\text { of Innovation and }\end{array}$} \\
\hline \multirow[t]{2}{*}{ Entrepreneurship } & 3 & Regional Studies & 2 \\
\hline & & $\begin{array}{l}\text { Asia Pacific Journal } \\
\text { of Innovation and }\end{array}$ & \\
\hline Journal of Macroeconomics & 3 & Entrepreneurship & 2 \\
\hline Journal of Cleaner & & Others- Journals with (1) & \\
\hline Production & 3 & Publication & 184 \\
\hline & & Others- Conference & \\
\hline Tourism Management & 3 & Proceedings & 97 \\
\hline
\end{tabular}

Table 1 highlights the 437 articles published in 320 different journals and conference proceedings. Research Policy is the only journal with a high ten publication mark, few within 5-10 range, and a number falling in the 2-4 scope. Nevertheless, most of the journals had just one publication, whereas conference proceedings had a significant amount of documents.

Number of publications per year 
Figure 2 presents the number of articles that have published over the years. There was moderate growth in a number of these publications between 1992 and 2008. From a general perspective, however, there is a steady rise in published articles from 2009 to 2018. Innovation is critical for the survival of any firm given the dynamism of the business environment, changes in technology, and ever-growing consumer demands. The importance of innovation in enhancing the competitiveness of an entity cannot be overemphasized (Ciocanel \& Pavelescu, 2015; Distanont \& Khongmalai, 2018). Besides, business is now forced to find strategic fits between adopted innovation strategies and the business environment in which they operate to improve on their performance and delivery (Prajogo, 2016). The 2007/8 Global Financial Crisis (GFC) was a turning point for most businesses, and this has captured in many studies (Driver \& Muñoz-Bugarin, 2019; Tsuruta, 2019).

Similarly, technological changes dictate reviewing of business models, for example, Lin (2017) explains the importance of collaborations aimed at transferring (innovation) knowledge between universities and the industry (Baglieri, Baldi, \& Tucci, 2018). Additionally, some firms are now forming strategic partnerships to harness their respective competitive advantages. Therefore, the reasons mentioned above may partly explain the increase in studies focusing on innovation.

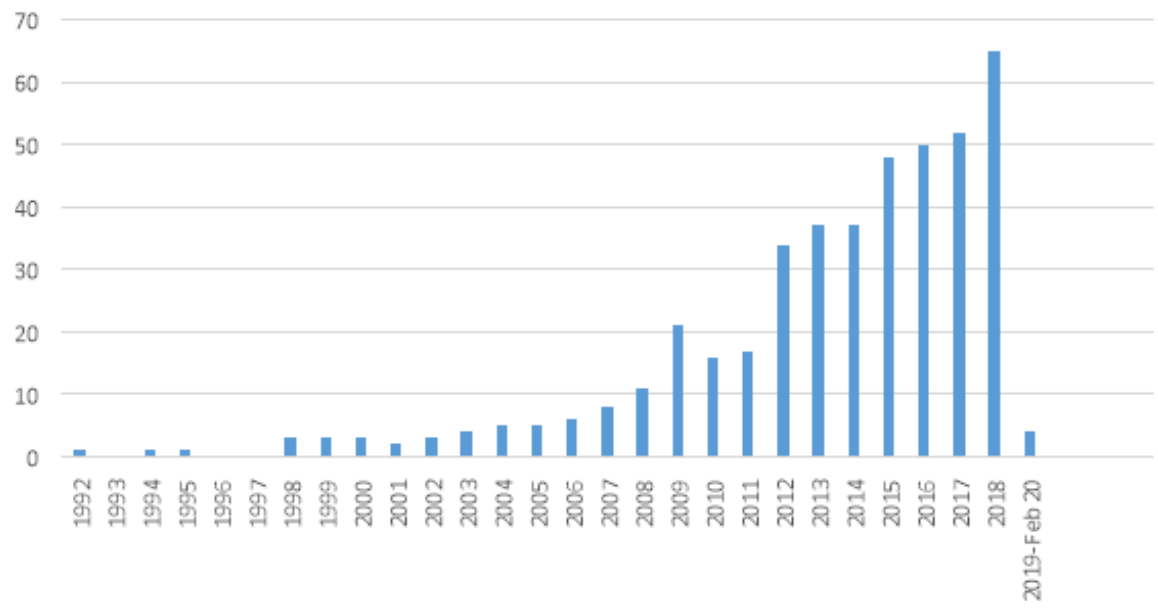

Figure 2. Number of articles published per year

Studies focusing on innovation continue to increase over the years, and this may be the trend in the foreseeable future for some reason. According to [1], 84 percent of the executives concur that innovation is key to a firm's 
growth strategies; however, only 6 percent are satisfied with the performance of innovation or rather understand what the problem is precisely and how to enhance innovation and R\&D activities in their enterprises. For a firm to survive today's competitive business environment, innovation has to be part of the strategy. [2] report shows that only 12 percent of the Fortune 500 enterprises from 1955 are still operational. Moreover, [3] shows that 50 percent of the S\&P 500 firms may be replaced in the next decade, signifying the importance of rapid response to external challenges. There is a clear distinction in both revenues (11 percent) and Earnings before Inflation Tax Depreciation and Amortization (22 percent) growth favoring more innovative enterprises [4].

\section{Publications per country}

Figure 3 shows affiliated publications in a given state. To be considered under this category, a country must have had a minimum of 5 publications. International collaborations in research are crucial for any country; uneven global collaboration impacts negatively the practicality of countries' scientific results and expected technological and social effect (Zanotto, Haeffner, \& Guimarães, 2016). From the findings, the United States has the most significant number of co-authored articles, followed by England and then the rest.

Furthermore, apart from the United States, most articles are from European countries, few from Latin America and Asia. However, no country from Africa or the Middle East met the cut implying a low level of coauthorship from these two regions. However, innovative, collaborative studies between countries are crucial in the production and dissemination of knowledge. Zhao, $\mathrm{Wu}, \mathrm{Xi}, \mathrm{Na}$, and Liu (2018) analyzed how a collaborative innovation approach can evolve into a competitive knowledge-intensive alliance by focusing on China, Korea, and Germany. The study also provides new insights and methods for performing collaborative studies between researchers in different countries. Gorraiz, Reimann, and Gumpenberger (2012) explain the principal elements and what should be in the evaluation of international research collaboration by examining Austria and six other countries (Choi, 2012; Kim, 2006).

The under this category publications examined the extent to which countries (authors) engage in collaborative scholarly work across borders. Based on the findings, it is possible to deduce that economies with the higher implementation of innovative activities also have a higher output of collaborative studies. 


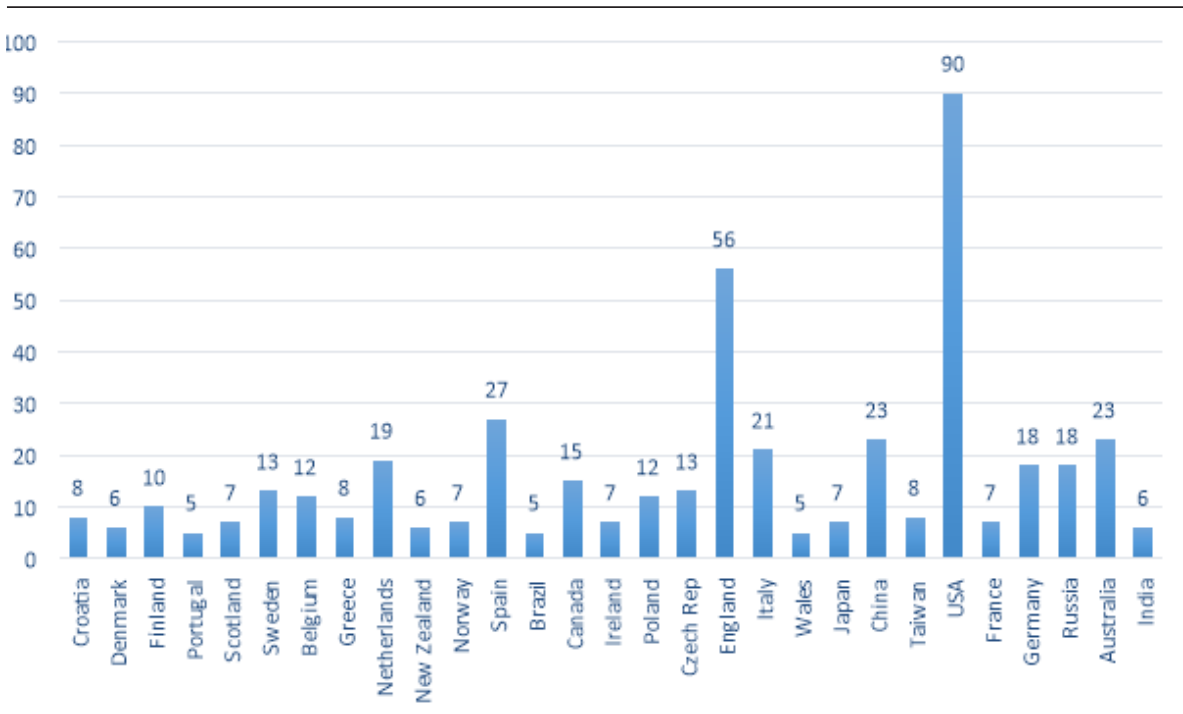

Figure 3. Publications affiliations by country

Number of published articles through collaborations of higher education institutions

Figure 4 illustrates articles published by way of institutional partnerships. Enough empirical literature exists to support continued collaborative studies among academic institutions. Bozeman, Fay, and Slade (2013) probed individual-level collaborations among academic researchers, focusing on university researchers' partnerships with researchers in other areas and industry. The study offers recommendations for improving on such collaborative studies such as increased consideration to multi-levels of analysis and the interplay amongst them; realistic evaluation of impacts rather than outputs; highlighting 'malpractice' and exploitations in these collaborations if any; giving some attention to collaborators' inspiration or the motivation of collaborative teams. Figure 2 shows that based on related research, collaborative studies among institutions of higher learning range between 2 and 5, the cut-off had been set at a minimum of two. England has more academic institutions' engaging in collaborative research.

Additionally, based on the findings, institutions of higher learning in Africa, Asia, and Middle East engagement in collaborative research is almost non-existent. Moreover, collaboration breadth has a direct effect, whereas collaboration depth has a curvilinear impact on academic research performance (Yuandi Wang, Hu, Li, Li, \& Li, 2015). Collaborative research is an 
alternative way of measuring research performance in institutions of higher learning (Kim, Lim, \& Lee, 2014).

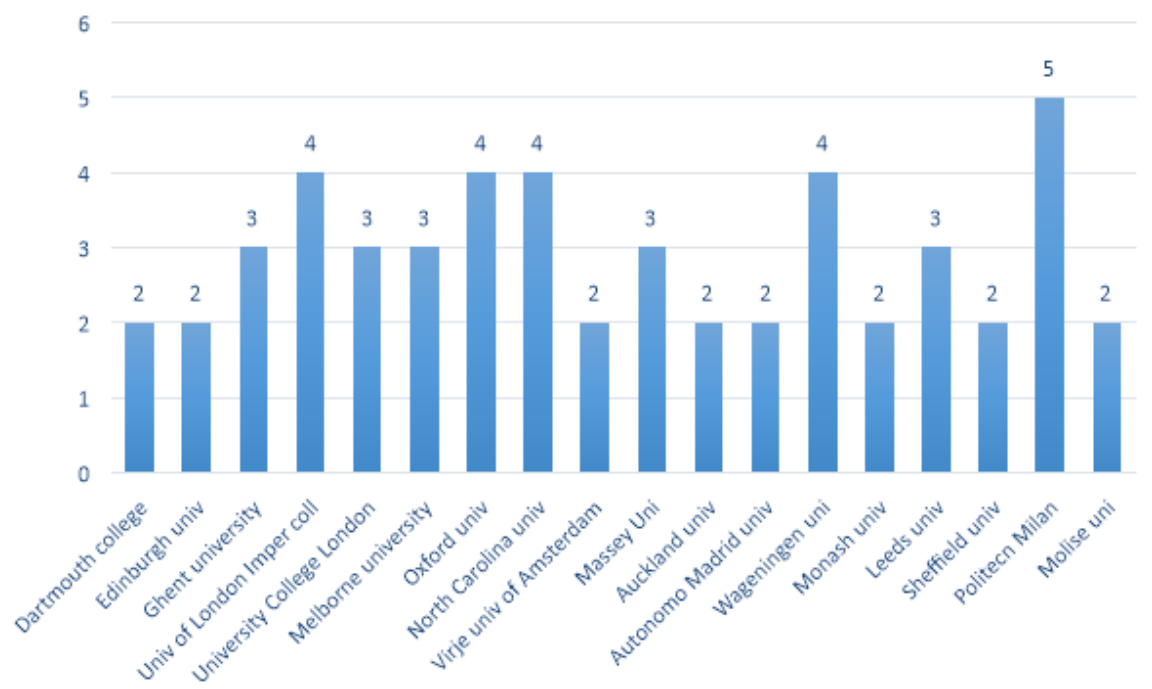

Figure 4. Number of articles authored through institutional collaboration

The findings under this section tend to support those found in the affiliation publications in a given country. Most of the institutions of higher learning partnering in academic work on innovation are from those countries highlighted in the previous section. These findings concur with the work of Crudu (2020), who explains that innovation is more pronounced in states with higher incomes and higher development levels.

Figure 5 is the scientific network of reviewed documents that comprised of 13 clusters, as illustrated by the different color shades. A particular group consists of articles associated with each other based on the strength of the links. Related articles are clustered together under one shade, whereas those in between or among different clusters take the mixture of the associated groups, as shown by the linking lines. Still, the stronger the tone of a circle (article) and track (network), the stronger the link between the publications. 


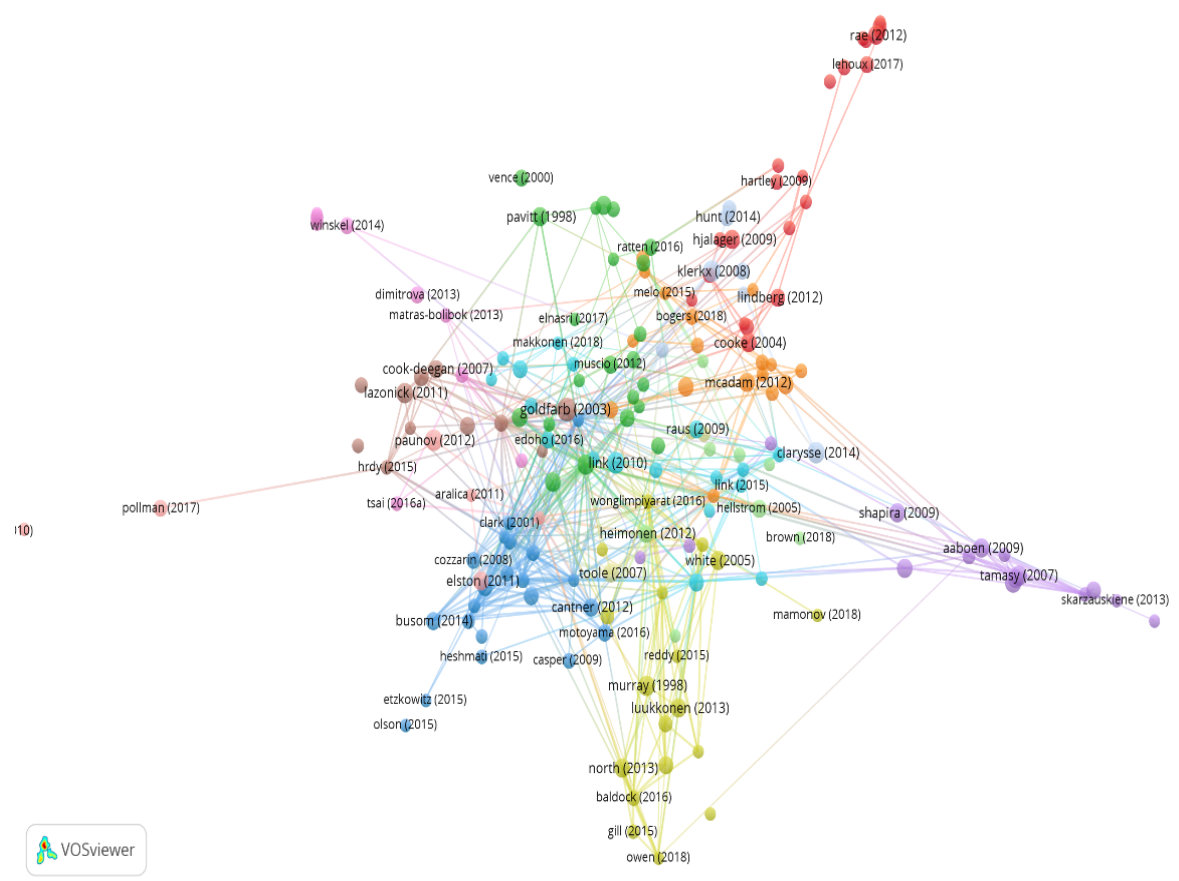

Figure 5. A bibliographic system of connected articles

Themes of reviewed publications

Figure 6 shows the items used to group the 13 clusters presented in Figure 5. These themes or the 13 clusters can be broken down further into three main categories based on the number of articles. These categories are very high, high, moderate, and intermediate impact publications groupings. Type one, on very high impact, consists of themes or clusters with a high number of publications, the items are; policy, economic growth, and research and development/incentives. Category two, top impact publications consist of themes with the second-highest number of documents, which include; funding, business incubation, entrepreneurship, and institutionalization of innovation. Category three consists of life science innovation, and the last category have themes focusing on; sustainability, financial decisions, network/ecosystem, agriculture, and biotechnology. 


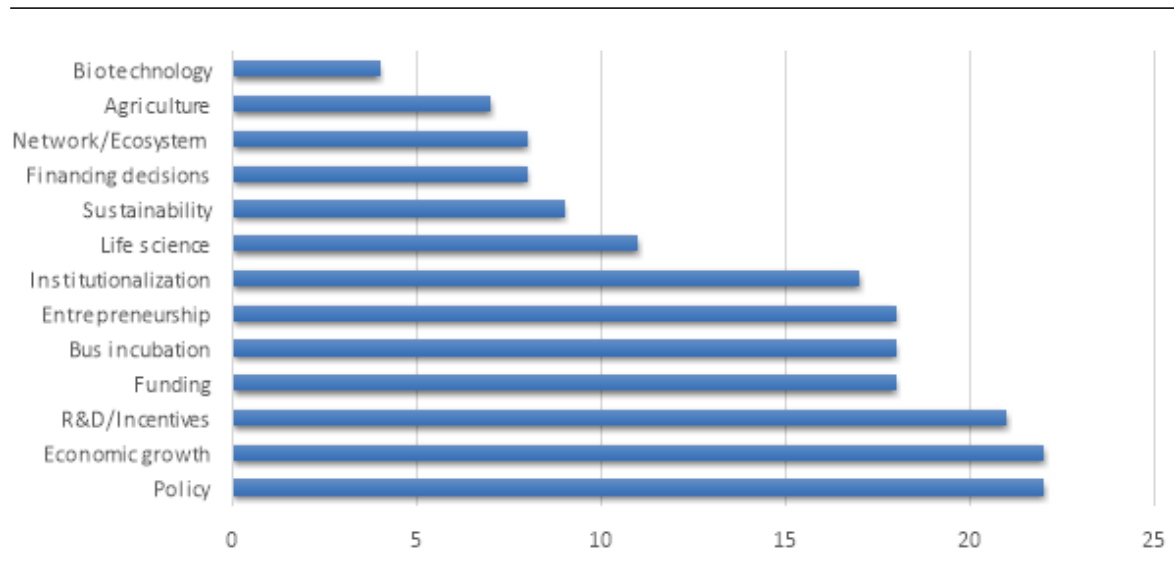

Figure 6. Themes of reviewed articles

\section{Themes and summaries of selected reviewed publications}

This section has into three parts; part one contains the various materials examined, part two outlines the 32 selected articles, and their corresponding citations, while part three, is a summary of these chosen articles.

\section{Themes and associated publications}

Table 2 represents the articles that constitute a given theme. That notwithstanding, some documents were not included in this section for reasons expounded on under methodology. The higher the standing/level of the group or theme, the higher is the number of the document.

\section{Citation analysis}

The citation evaluation of the reviewed literature was done using the document as a unit of study. Only 242 out of the 437 articles had been cited at least once or more, which was the cut-off criteria, as presented by Figure 7. Table 3 shows selected documents from the 242 and their associated level of citation as per the Web of Science. Based on association rule and a requirement of 20 citations, 32 articles were finally selected, as shown. The most cited article is by Goldfarb and Henrekson (2003) at 231citations, whereas a study by comes a distant second, Clarysse et al. (2014), at 96 citations. The remaining publications had citations ranges of between 22 and 81 . 
Table 2. Themes of reviewed studies

\begin{tabular}{|c|c|c|}
\hline Group & Theme & Article/Author \\
\hline 1 & Policy/Regulation & $\begin{array}{l}\text { Sá, Kretz, and Sigurdson (2013); Calo (2018); Cooke } \\
\text { (2004); de Laurentis (2012); De Lucia, Balena, } \\
\text { Stufano Melone, and Borri (2016); Dodescu and } \\
\text { Chirilă (2013); Gilmore and Comunian (2016); Kasa } \\
\text { Underthun (2010); Jordan, Lemken, and Liedtke } \\
\text { (2014); Greenhalgh et al. (2017); Hartley and } \\
\text { Montgomery (2009); Reficco and Gutiérrez (2016); } \\
\text { Moreton (2016); Rae et al. (2012); Gurzawska, } \\
\text { Mäkinen, and Brey (2017); Parvizi and Parvizi } \\
\text { (2017); Seppo, Rõigas, and Varblane (2014); Tan } \\
\text { (2018); Witten et al. (2018); Lindberg, Danilda, and } \\
\text { Torstensson (2012). }\end{array}$ \\
\hline 2 & Economic Growth/Collaboration & $\begin{array}{l}\text { Antonioli, Marzucchi, and Montresor (2014); } \\
\text { Cumming, Johan, and Zhang (2014); Klerkx and } \\
\text { Leeuwis (2008); Lynskey (2004); Domingo and } \\
\text { Soriano (2014); Mendes, Serrasqueiro, and Nunes, } \\
\text { (2014); Nelson (1995); Pavitt (1998); Muscio and } \\
\text { Nardone (2012); Lynch, Lenihan, and Hart (2009); } \\
\text { Hemphill (2013); Vickers and North (2000); Rubach } \\
\text { (2013); Fogg (2012); Yan, Chien, Hong, and Yang } \\
\text { (2018); Vence and Gunti (2000); Ratten, Ferreira, } \\
\text { and Fernandes (2016); Elnasri and Fox (2017); } \\
\text { Fundeanu and Badele (2014). }\end{array}$ \\
\hline 3 & R\&D/Incentives & $\begin{array}{l}\text { Afcha and León López (2014); Kenney and Patton } \\
\text { (2018); Cozzarin (2008); Lanahan (2016); Wu, } \\
\text { Popp, Bretschneider, Maxwell, and Policy (2007); } \\
\text { Engel, Rothgang, and Eckl (2016); Heshmati } \\
\text { (2015); Cantner and Kösters (2012); Olson and } \\
\text { Young (2016); Etzkowitz and Etzkowitz (2015); } \\
\text { Busom, Corchuelo, and Martínez-Ros (2014); } \\
\text { Czarnitzki (2014); Archibugi and Filippetti (2018); } \\
\text { Wang, Li, and Furman (2017); Jr. and Paolucci } \\
\text { (2004); Michalsen (2006). }\end{array}$ \\
\hline 4 & Funding & $\begin{array}{l}\text { Owen, Brennan, and Lyon (2018); Campos, Coville, } \\
\text { Fernandes, Goldstein, and McKenzie (2014); } \\
\text { Gill (2015); Baldock (2015); North, Baldock, } \\
\text { and Ullah (2013); Collewaert, Manigart, and } \\
\text { Aernoudt (2010); Henrekson and Sanandaji (2018); } \\
\text { Luukkonen, Deschryvere, and Bertoni (2013a); } \\
\text { Murray (1998); Mamonov and Malaga (2018); } \\
\text { Kolesnyk (2017); White, Gao, and Zhang (2005); } \\
\text { Das, Hui, and Sha (2018); Wonglimpiyarat (2016). }\end{array}$ \\
\hline 5 & Business Incubation & $\begin{array}{l}\text { Aaboen (2009); Frenkel, Shefer, and Miller (2005); } \\
\text { Mubarak et al. (2015); Löfsten and Lindelöf (2003); } \\
\text { Tamásy (2007); Tang, Baskaran, Pancholi, and Lu } \\
\text { (2013); Dvouletý, Longo, Blažková, Lukeš, and } \\
\text { Andera (2018); Cumming and Fischer (2012); } \\
\text { Shapira and Wang (2009); Appelbaum, Gebbie, } \\
\text { Han, Stocking, and Kay (2016); Breznitz and } \\
\text { Ornston (2018); Walwyn and Cloete (2016); } \\
\text { Perampaladas et al. (2010); Chakma, Masum, and } \\
\text { Singer (2010). }\end{array}$ \\
\hline
\end{tabular}




\begin{tabular}{|c|c|c|}
\hline Group & Theme & Article/Author \\
\hline 6 & Entrepreneurship & $\begin{array}{l}\text { Bearse and Link (2010); Costa, Laureano, and } \\
\text { Laureano (2014); Pergelova and Angulo-Ruiz } \\
\text { (2014); Welsh, Kaciak, Trimi, and Mainardes } \\
\text { (2018); Link and Scott (2010); Divisekera and } \\
\text { Nguyen (2018); Makkonen, Williams, Weidenfeld, } \\
\text { and Kaisto (2018); Kalisz and Aluchna (2012); } \\
\text { Rószkiewicz (2014); (Petrescu, 2009); Edoho } \\
\text { (2016); Sjøvaag and Krumsvik (2017);(Link and } \\
\text { Wright (2015). }\end{array}$ \\
\hline 7 & Institutionalization/Academia & $\begin{array}{l}\text { Venturini and Verbano (2017); Bengtsson (2017); } \\
\text { Rizos et al. (2016); Rosli and Rossi (2016); Wolley } \\
\text { (2016); McAdam, Miller, McAdam, and Teague } \\
\text { (2012); Minshall, Schmithausen, Kouris, Mortara, } \\
\text { and Weiss (2013); Jaekel, Wallin, and Isomursu } \\
\text { (2015); Holm (2015); Bogers, Chesbrough, and } \\
\text { Moedas (2018); Meissner (2018); Zhang et al. } \\
\text { (2018); Catulli and Frye, (2012); Antony, Johnson } \\
\text { and, Sin field (2008). }\end{array}$ \\
\hline 8 & Life science & $\begin{array}{l}\text { Bar-Shalom and Cook-Deegan (2002); Lazonick and } \\
\text { Tulum (2011); Bar-Shalom and Cook-Deegan (2002); } \\
\text { Goldfarb and Henrekson (2003); Evens and Kaitin } \\
\text { (2015); Džupka, Klasová, and Kováč, (2016); Ghauri } \\
\text { and Rao (2009); Kolympiris, Kalaitzandonakes, and } \\
\text { Miller (2014);Rdy et al. (2014). }\end{array}$ \\
\hline 9 & Sustainability & $\begin{array}{l}\text { Malen and Marcus (2017); Chirambo (2018); } \\
\text { Dimitrova (2013); Winskel, Radcliffe, Skea, and } \\
\text { Wang (2014); Kolk (2015); Bumpus (2015); Bointner, } \\
\text { Pezzutto, Grilli, and Sparber (2016). }\end{array}$ \\
\hline 10 & Financing decisions & $\begin{array}{l}\text { Concilio, Molinari, and Morelli (2017); Elston and } \\
\text { Audretsch (2011); Pike (2010); Paunov, (2012); } \\
\text { Padilla-Ospina, Medina-Vásquez, and Rivera- } \\
\text { Godoy (2018); Pollman and Barry (2016). }\end{array}$ \\
\hline 11 & Network/Ecosystems & $\begin{array}{l}\text { Heimonen (2012); Heimonen (2012); Begonja, } \\
\text { Čićek, Balboni, and Gerbin (2016); Hellström and } \\
\text { Jacob (2005); Rubach (2013); Brown et al. (2018); } \\
\text { Samford, Warrian, and Goracinova (2017). }\end{array}$ \\
\hline 12 & Agriculture & $\begin{array}{l}\text { Klerkx and Leeuwis (2008); Clarysse, Wright, } \\
\text { Bruneel, and Mahajan (2014); Sisko Patana, } \\
\text { Pihlajamaa, Polvinen, Kanto, and Carleton (2013); } \\
\text { Hoppe and Sanders (2014); Hunt, Birch, Vanclay, } \\
\text { and Coutts (2014); Ton, Klerkx, de Grip, and Rau } \\
\text { (2015); Gava, Favilli, Bartolini, and Brunori (2017). }\end{array}$ \\
\hline 13 & Biotechnology & $\begin{array}{l}\text { Toole and Czarnitzki (2007); Bagchi-Sen and Scully } \\
\text { (2004); Chang and Tsai (2016). }\end{array}$ \\
\hline
\end{tabular}




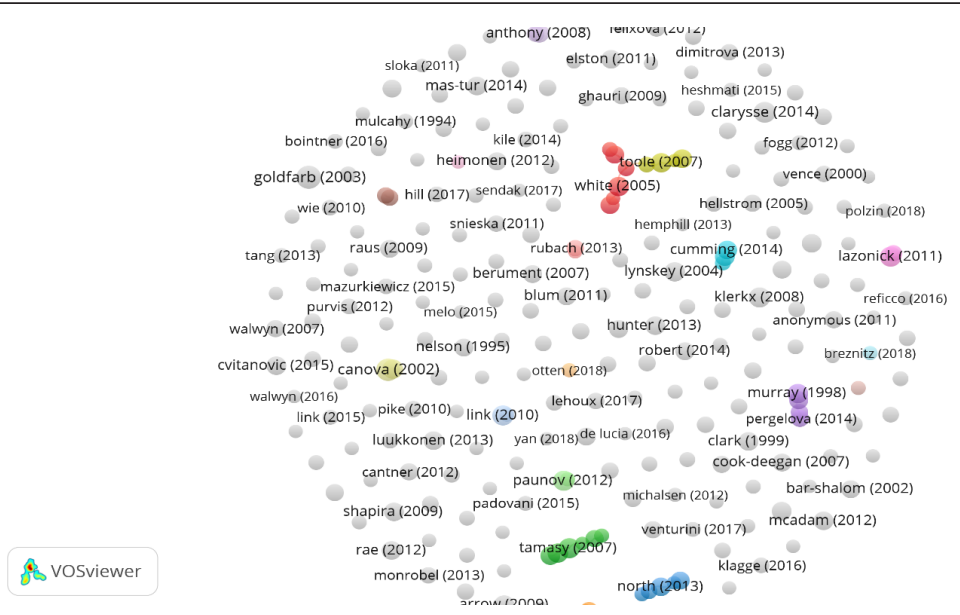

Figure 7. Citation network of 242 out of 437 publications reviewed

Table 3. Ranking publications by the number of citations received

\begin{tabular}{|c|c|c|}
\hline Author & Title & Citations \\
\hline Aaboen (2009) & Explaining incubators using a firm analogy & 35 \\
\hline $\begin{array}{l}\text { Clarysse, Wright } \\
\text { Bruneel and, } \\
\text { Mahajan (2014) }\end{array}$ & $\begin{array}{l}\text { Creating value in ecosystems: Crossing the chasm between } \\
\text { knowledge and business ecosystems }\end{array}$ & 96 \\
\hline $\begin{array}{l}\text { Cumming and } \\
\text { Fischer (2012) }\end{array}$ & $\begin{array}{l}\text { Publicly funded business advisory services and } \\
\text { entrepreneurial outcomes }\end{array}$ & 28 \\
\hline $\begin{array}{l}\text { Löfsten and } \\
\text { Lindelöf (2003) }\end{array}$ & $\begin{array}{l}\text { Determinants of entrepreneurial milieu: Science parks and } \\
\text { business policy in growing firms }\end{array}$ & 44 \\
\hline $\begin{array}{l}\text { Shapira and Wang } \\
\text { (2009) }\end{array}$ & $\begin{array}{l}\text { From lab to market: Issues and strategies in the } \\
\text { commercialization of nanotechnology in China }\end{array}$ & 37 \\
\hline $\begin{array}{l}\text { Sofouli and } \\
\text { Vonortas (2007) }\end{array}$ & $\begin{array}{l}\text { S\&T parks and business incubators in middle-sized countries: } \\
\text { The case of Greece }\end{array}$ & 34 \\
\hline Tamásy (2007) & $\begin{array}{l}\text { Rethinking technology business-oriented incubators: } \\
\text { Developing a robust policy instrument for entrepreneurship, } \\
\text { innovation and, development }\end{array}$ & 60 \\
\hline Czarnitzki (2014) & $\begin{array}{l}\text { Innovation subsidies: Does the funding source matter for } \\
\text { innovation intensity and Intensity? Empirical evidence from } \\
\text { Germany }\end{array}$ & 23 \\
\hline $\begin{array}{l}\text { Link and Scott } \\
\text { (2010) }\end{array}$ & $\begin{array}{l}\text { Government as an entrepreneur: Evaluating the } \\
\text { commercialization success of SBIR projects }\end{array}$ & 71 \\
\hline Lynskey (2004) & $\begin{array}{l}\text { Determinants of innovative activity in Japanese Technology- } \\
\text { based start-up firms }\end{array}$ & 44 \\
\hline $\begin{array}{l}\text { Domingo and } \\
\text { Soriano (2014) }\end{array}$ & $\begin{array}{l}\text { The level of innovation among young innovative companies: } \\
\text { The impacts of knowledge-intensive services use, firm } \\
\text { characteristics and the entrepreneur attributes }\end{array}$ & 33 \\
\hline
\end{tabular}




\begin{tabular}{|c|c|c|}
\hline Author & Title & Citations \\
\hline Paunov (2012) & The global crisis and firms' investments in innovation & 71 \\
\hline $\begin{array}{l}\text { Toole and } \\
\text { Czarnitzki (2007) }\end{array}$ & $\begin{array}{l}\text { Biomedical academic entrepreneurship through the SBIR } \\
\text { program }\end{array}$ & 41 \\
\hline $\begin{array}{l}\text { Bar-Shalom and } \\
\text { Cook-Deegan } \\
\text { (2002) }\end{array}$ & $\begin{array}{l}\text { Patents and innovation in cancer therapeutics: Lessons from } \\
\text { CellPro }\end{array}$ & 21 \\
\hline Cooke (2004) & Life science clusters and regional science policy & 27 \\
\hline Hjalager (2009) & Cultural Tourism Innovation Systems - The Roskilde Festival & 26 \\
\hline $\begin{array}{l}\text { Klerkx and Leeuwis } \\
\text { (2008) }\end{array}$ & $\begin{array}{l}\text { Balancing multiple interests: Embedding innovation } \\
\text { intermediation in the agricultural knowledge infrastructure }\end{array}$ & 81 \\
\hline $\begin{array}{l}\text { Lazonick and } \\
\text { Tulum (2011) }\end{array}$ & $\begin{array}{l}\text { US biopharmaceutical finance and the sustainability of the } \\
\text { biotech business model }\end{array}$ & 63 \\
\hline $\begin{array}{l}\text { Antony, Johnson } \\
\text { and, Sin field } \\
\text { (2008) }\end{array}$ & Institutionalizing innovation & 27 \\
\hline $\begin{array}{l}\text { Cumming, Johan } \\
\text { and, Zhang (2014) }\end{array}$ & $\begin{array}{l}\text { The economic impact of entrepreneurship: Comparing } \\
\text { international datasets }\end{array}$ & 30 \\
\hline $\begin{array}{l}\text { Goldfarb and } \\
\text { Henrekson (2003) }\end{array}$ & $\begin{array}{l}\text { Bottom-up versus top-down policies towards the } \\
\text { commercialization of university intellectual property }\end{array}$ & 231 \\
\hline Heimonen (2012) & What are the factors that affect innovation in growing SMEs? & 22 \\
\hline $\begin{array}{l}\text { Collewaert, } \\
\text { Manigart and, } \\
\text { Aernoudt (2010) }\end{array}$ & $\begin{array}{l}\text { Assessment of government funding of business angel } \\
\text { networks in Flanders }\end{array}$ & 22 \\
\hline $\begin{array}{l}\text { Elston and } \\
\text { Audretsch (2011) }\end{array}$ & $\begin{array}{l}\text { Financing the entrepreneurial decision: An empirical approach } \\
\text { using experimental data on risk attitudes }\end{array}$ & 27 \\
\hline $\begin{array}{l}\text { Elston and } \\
\text { Audretsch (2011) }\end{array}$ & $\begin{array}{l}\text { Funding the growth of UK technology-based small firms } \\
\text { since the financial crash: are there breakages in the finance } \\
\text { escalator? }\end{array}$ & 32 \\
\hline $\begin{array}{l}\text { Luukkonen, } \\
\text { Deschryvere and, } \\
\text { Bertoni (2013) }\end{array}$ & $\begin{array}{l}\text { The value added by government venture capital funds } \\
\text { compared with independent venture capital funds }\end{array}$ & 30 \\
\hline Murray (1998) & $\begin{array}{l}\text { A policy response to regional disparities in the supply of risk } \\
\text { capital to new technology-based firms in the European Union: } \\
\text { The European seed capital fund scheme }\end{array}$ & 48 \\
\hline $\begin{array}{l}\text { White, Gao and, } \\
\text { Zhang (2005) }\end{array}$ & $\begin{array}{l}\text { Financing new ventures in China: System antecedents and } \\
\text { institutionalization }\end{array}$ & 41 \\
\hline $\begin{array}{l}\text { McAdam, Miller, } \\
\text { McAdam and, } \\
\text { Teague (2012) }\end{array}$ & $\begin{array}{l}\text { The development of university technology transfer- } \\
\text { stakeholder relationships at a regional level: Lessons for the } \\
\text { future }\end{array}$ & 35 \\
\hline Rizos et al. (2016) & $\begin{array}{l}\text { Implementation of circular economy business models by small } \\
\text { and medium-sized enterprises (SMEs): Barriers and enablers }\end{array}$ & 26 \\
\hline Nelson (1995) & Why should managers be thinking about technology policy? & 26 \\
\hline Pavitt (1998) & The inevitable limits of EU R\&D funding & 33 \\
\hline
\end{tabular}




\section{A summary of selected publications}

Table 4 provides an overview of the 32 chosen documents considered significant based on the citation levels. The summary is necessary for providing information on these studies in a short and precise way. Most of the publications focused on mature economies in Europe, the United States, and a few on emerging such as China. Once again, there are no studies on emerging economies. Nevertheless, the publications are even for quantitative and qualitative studies.

Table 4. Summaries of selected articles

\begin{tabular}{|c|c|c|}
\hline Theme & Study & Summary of the Study \\
\hline Funding & Aaboen (2009) & $\begin{array}{l}\text { The case study uses the analogy of a professional service firm } \\
\text { to describe an incubator by stressing on attributes related } \\
\text { to resources. The important attributes being an enlistment } \\
\text { of new technology-based firms (NTBFs), service delivery, } \\
\text { knowledgeable staff, and resource base. Moreover, an } \\
\text { improvement in these attributes relates to the incubator's } \\
\text { progress with the increased complicatedness of the resource } \\
\text { base minimizing chances of imitation. The authors submit that } \\
\text { an incubator may have numerous clients with diverse value } \\
\text { creation processes or none at all, depending on the context. } \\
\text { Region: Sweden; Study: qualitative; Period:2003-2005. }\end{array}$ \\
\hline
\end{tabular}

Business Incubation Cumming and The authors empirically interrogate the effectiveness Fischer (2012) of publicly financed business advisory services and entrepreneurial results. The study finds a positive relationship between advisory services and growth in firms, patents, financing, and strategic alliances. Region: Canada; Study: quantitative; Duration: over five years Period: 2008-2009.

Löfsten and The survey study differentiates between new technologyLindelöf (2003) based entities (NTBFs) within and without Science Parks to single out any factor of the added value provided by the parks to these new technology-based firms. NTBFs inside the Park is found to have a greater market distribution within and without Sweden as compared to typical small entities. Region: Sweden; Study: quantitative; Period:1996-1998.

Shapira and The conceptual study analyses the gap between

Wang (2009) nanotechnology researches and assesses future commercialization trajectories of such researches. The study offers two avenues for commercializing enhanced R\&D developments in nanotechnology. The commercialization can be through spill-over from the academic sector and spillover from foreign firms. Region: China; Study: qualitative; Period:1990-2006.

Tamásy (2007) The survey queries political rationales, explores appraisal literature, and outlines proposals for the future of the business incubation industry. The study argues against public funding of technology-oriented business incubators, instead suggests that they are running as private organizations. 


\begin{tabular}{|c|c|c|}
\hline Theme & Study & Summary of the Study \\
\hline & $\begin{array}{l}\text { Sofouli and } \\
\text { Vonortas (2007) }\end{array}$ & $\begin{array}{l}\text { The conceptual study connects the policy on science and } \\
\text { technology to the goals and features of the well-established } \\
\text { parks and incubators. The authors argue that science, } \\
\text { technology parks, and incubators in-country ownership } \\
\text { and management have moved from academic or research } \\
\text { institutes to private players. }\end{array}$ \\
\hline & & $\begin{array}{l}\text { Similarly, financing, the supply of seed capital and venture } \\
\text { capital has shifted from government to the private sector. } \\
\text { Region: Greece; Study: qualitative.. }\end{array}$ \\
\hline \multirow[t]{2}{*}{ R\&D/Incentive } & $\begin{array}{l}\text { Czarnitzki } \\
(2014)\end{array}$ & $\begin{array}{l}\text { The survey study explores the impact of European policies and } \\
\text { public financing on both innovation input and output for the } \\
\text { firm. On innovation input, the policies complement each other. } \\
\text { On output, subsidy beneficiaries are active in terms of patents. } \\
\text { Thus, public funding stimulates socially beneficial research } \\
\text { endeavors, while the presence of both national and European } \\
\text { policies has no crowding-out effect. Region: Germany; Study: } \\
\text { quantitative; Period:1992-1994 }\end{array}$ \\
\hline & Paunov (2012) & $\begin{array}{l}\text { The survey analyses the long term effect of the global financial } \\
\text { crisis on business innovation activities to formulate necessary } \\
\text { post-recovery policy framework. The authors focus on firms } \\
\text { in eight Latin American countries. The study finds that such } \\
\text { a crisis results in many firms halting ongoing innovation } \\
\text { program; however, entities accessing public funding are } \\
\text { unlikely to stop these projects. Region: Latin America; Study: } \\
\text { quantitative; Period: } 2008-2009 \text {. }\end{array}$ \\
\hline \multirow[t]{3}{*}{$\begin{array}{l}\text { Collaboration/ } \\
\text { Economic Growth }\end{array}$} & Lynskey (2004) & $\begin{array}{l}\text { The study examines the determinants of innovation, based } \\
\text { on patent registrations and new products for technology- } \\
\text { based start-up firms in Japan. The authors conclude that } \\
\text { technological capacity, the availability of internal financial } \\
\text { resources, venture capital funding, and academia-industry } \\
\text { collaborations are crucial determinants of innovation at } \\
\text { the firm level. Additionally, educational qualifications and } \\
\text { the ability of the chief executive officer to network with } \\
\text { researchers are fundamental managerial characteristics. } \\
\text { Region: Japan; Study: qualitative. }\end{array}$ \\
\hline & $\begin{array}{l}\text { Domingo and } \\
\text { Soriano (2014) }\end{array}$ & $\begin{array}{l}\text { The survey probes on the characteristics that improve } \\
\text { innovation and adoption of knowledge-intensive business } \\
\text { services support for driving innovation in young innovative } \\
\text { firms. Further, the study links the level of innovation among } \\
\text { these innovative firms to the entities' attributes and the } \\
\text { entrepreneurs' characteristics. The authors conclude that the } \\
\text { use of knowledge-intensive business services stirs innovation } \\
\text { in young innovative companies. Region: Spain; Study: } \\
\text { quantitative; Period: } 2009 \text { - } 2010 \text {. }\end{array}$ \\
\hline & Pavitt (1998) & $\begin{array}{l}\text { The study aimed at provoking a discussion at a time when } \\
\text { there was a general feeling that policies and systems for } \\
\text { funding of research and development in the European Union } \\
\text { had challenges relating to budgetary constraints, political } \\
\text { hurdles, and varying ideas on what the right policy ought to } \\
\text { have been Region: EU; Study: qualitative. }\end{array}$ \\
\hline
\end{tabular}




\begin{tabular}{|c|c|c|}
\hline Theme & Study & Summary of the Study \\
\hline & Nelson (1995) & $\begin{array}{l}\text { The author details three significant aspects of contemporary } \\
\text { technology policy, which are significantly crucial to the } \\
\text { business. These are; applied for research support by the } \\
\text { government, managing declines in basic research funded by } \\
\text { corporations, and complex matters on intellectual property } \\
\text { rights (IRS) Region: general; Study: qualitative. }\end{array}$ \\
\hline Funding & $\begin{array}{l}\text { Collewaert, } \\
\text { Manigart and, } \\
\text { Aernoudt } \\
(2010)\end{array}$ & $\begin{array}{l}\text { The survey appraises whether government intervention, } \\
\text { such as the subsidization of business angel networks (BANs), } \\
\text { promotes regional economic development. The study } \\
\text { concludes that BANs minimize the challenges associated } \\
\text { with information and financing faced by entrepreneurial } \\
\text { firms. Additionally, these firms add to economic growth or } \\
\text { expansion. Finally, such a program has several desirable } \\
\text { indirect effects, implying that BAN support by the public is } \\
\text { necessary. Region: Belgium; Study: qualitative. }\end{array}$ \\
\hline \multirow[t]{3}{*}{ Entrepreneurship } & $\begin{array}{l}\text { Link and Scott } \\
\text { (2010) }\end{array}$ & $\begin{array}{l}\text { The survey focuses on the Small Business Innovation Research } \\
\text { (SBIR) program. The authors show that the innovative } \\
\text { utilization of public resources through the SBIR programs } \\
\text { aimed at targeting and supporting research activities in small } \\
\text { firms tends to minimize innovation impediments that make } \\
\text { small entities to underinvest in research and development. } \\
\text { Region: United States; Study: quantitative. }\end{array}$ \\
\hline & Hjalager (2009) & $\begin{array}{l}\text { The case study examines cultural tourism from an innovation } \\
\text { point of view. Focusing on Denmark's Roskilde Festival as } \\
\text { a case study, the authors describe how different organizational } \\
\text { frameworks have been developed with political backing to } \\
\text { stimulate spin-offs. Additionally, there is a more substantial } \\
\text { representation of both the academic and research players. } \\
\text { Region: Denmark; Study: qualitative. }\end{array}$ \\
\hline & $\begin{array}{l}\text { Cumming, } \\
\text { Johan and, } \\
\text { Zhang (2014) }\end{array}$ & $\begin{array}{l}\text { The comparative study is focusing on the effect of } \\
\text { entrepreneurship on gross domestic product/capita, levels of } \\
\text { unemployment, exports/gross domestic product, and patents } \\
\text { registration per population across countries. The study finds } \\
\text { entrepreneurship has a significant positive impact on total } \\
\text { domestic product/capita, exports/ gross domestic product, } \\
\text { and patents registration per population; nonetheless, it hurts } \\
\text { levels of unemployment. Region: } 12 \text { countries in western and } \\
\text { eastern Europe; Study: quantitative; Period: 2004-2009. }\end{array}$ \\
\hline Policy/Regulation & Cooke (2004) & $\begin{array}{l}\text { The comparative analysis probes the likely impact on the } \\
\text { science-policy of shifts in R\&D-based clusters attributed to } \\
\text { the boost of knowledge-economies. The study focuses on } \\
\text { life sciences and ways by which Research and Development } \\
\text { led groupings to provide crucial resources such as innovative } \\
\text { businesses, research funding, and infrastructure in fewer } \\
\text { clusters. The authors recommend the provision of new region- } \\
\text { based science-policy tools for redistributing this knowledge } \\
\text { economy, which is an advantage more significant than just } \\
\text { supporting innovation. Region: the United States and the } \\
\text { United Kingdom; Study: qualitative. }\end{array}$ \\
\hline
\end{tabular}




\begin{tabular}{|c|c|c|}
\hline Theme & Study & Summary of the Study \\
\hline \multirow[t]{2}{*}{$\begin{array}{l}\text { Institutionalization/ } \\
\text { Academic }\end{array}$} & $\begin{array}{l}\text { Antony, Johnson } \\
\text { and, Sin field } \\
(2008)\end{array}$ & $\begin{array}{l}\text { The case study illustrates that successful innovation depends } \\
\text { on three main elements. These include growth blueprints, } \\
\text { where managers must know where the entity intends to be } \\
\text { and provide the necessary resources; innovation systems and } \\
\text { engines; their creation requires developing mechanisms to } \\
\text { screen and reduce uncertainty in the projects; right mind-sets, } \\
\text { through the creation of a supportive innovation environment } \\
\text { by senior managers. The authors finalize by detailing } \\
\text { a blueprint and checklist for converting an entity into an } \\
\text { innovation hub. Region: United States; Study: qualitative. }\end{array}$ \\
\hline & $\begin{array}{l}\text { McAdam, } \\
\text { Miller, McAdam } \\
\text { and, Teague } \\
(2012)\end{array}$ & $\begin{array}{l}\text { The case study reviews the link between Government } \\
\text { funding entities and technology transfer procedures by the } \\
\text { university. The findings indicate that higher targeted funding } \\
\text { and policy attributable to the stakeholder relationship } \\
\text { mechanism results in the expansion of joint systems with } \\
\text { close positioning of performance measures between the } \\
\text { technology transfer office and the regional development } \\
\text { agencies. Region: UK; Study: qualitative. }\end{array}$ \\
\hline
\end{tabular}

Rizos et al.

(2016)

Network/Ecosystem Heimonen The authors explain factors that affect the innovativeness of

(2012) thriving small and medium-sized entities using intellectual property rights (trademarks, patents, registered designs, and utility modes) as a measure of innovation. The findings suggest that flourishing intellectual property rights intensive entities face more financial pressures as compared to those producing nothing at all. Funding research and development through public finances enhances the chances of desirable innovation Region: Finland; Study: qualitative; Period: 2002-2005.

Financing Decisions Elston and The study combines both survey and experimental research Audretsch designs to explore the importance of personal funds in the (2011) entry decisions for high-tech entrepreneurs. The findings reveal that; small business innovation research grants (SBIR), use of credit cards, and salary for employed people top sources of funding for entrepreneurs wishing to set-up a firm. Furthermore, firm set-up depends on accessing capital in both initial and early phases of development, also funded by the government covering SBIR grants, is a vital source of financing high technology entrepreneurs. Region: US; Study: qualitative; Period: 2004.

Luukkonen, Deschryvere and, Bertoni (2013)
The comparative study examines the significance of an entity's growth of post-investment, value-added actions by government venture capital firms (GVC) and independent venture capital entities (IVC), based on a survey of growing high tech venture capital-backed firms in seven European countries. The study finds no significant disparity between the two sets of investors. However, the value-added varies depending on the type of investor, with the contributions of IVC funding being significantly higher than those of GVC funding. Besides, this is so in instances such as in the advancement of the business idea, exit strategy, and professionalization. Region: Belgium, Finland, Germany, France, Italy, Spain \& UK; Study: qualitative; Period: 2010 


\begin{tabular}{|c|c|c|}
\hline Theme & Study & Summary of the Study \\
\hline & $\begin{array}{l}\text { White, Gao and, } \\
\text { Zhang (2005) }\end{array}$ & $\begin{array}{l}\text { Through a survey study, the authors recommended a general } \\
\text { structure for the financing of new ventures as a result of } \\
\text { government policy on technology. The situation was at a time } \\
\text { when innovation was still a new phenomenon in China in the } \\
80 \text { s to early 2000s. The study had a policy and managerial } \\
\text { ramifications touching across varying venture funding systems. } \\
\text { Region: China; Study: qualitative. }\end{array}$ \\
\hline & Murray (1998) & $\begin{array}{l}\text { The study examines the European Seed Capital Fund Schemes } \\
\text { meant to address regional disparities in the availability of } \\
\text { risk-free capital for start-ups or new technology-based firms } \\
\text { within the European Union in the early 1990s. The scheme } \\
\text { was as a result of private venture capital providers lessening } \\
\text { their support for start-ups and early-stage technology- } \\
\text { based firms in the European Union; and, the presence of } \\
\text { spatial concentrations in the availability of venture capital } \\
\text { disadvantaged the creation of new, innovative entities in } \\
\text { under-developed parts of the Union. The scheme was found } \\
\text { to have achieved its objective of stimulating private funding } \\
\text { into young innovative technology-based businesses Region: } \\
\text { European Union; Study: qualitative. }\end{array}$ \\
\hline \multirow[t]{2}{*}{ Agricultural } & $\begin{array}{l}\text { Clarysse, Wright } \\
\text { Bruneel and, } \\
\text { Mahajan (2014) }\end{array}$ & $\begin{array}{l}\text { The authors empirically examine the knowledge and business } \\
\text { ecosystem of the financial support network. The study } \\
\text { finds that the knowledge ecosystem has a good framework } \\
\text { coalescing around some central actors, whereas the } \\
\text { business ecosystem is practically non-existent at the local } \\
\text { stage. Additionally, the financial support network is entirely } \\
\text { publicly supported and does not link to the knowledge and } \\
\text { business ecosystem. Region: Belgium; Study: quantitative; } \\
\text { Period:2005-2011. }\end{array}$ \\
\hline & $\begin{array}{l}\text { Klerkx and } \\
\text { Leeuwis (2008) }\end{array}$ & $\begin{array}{l}\text { The case study focuses on the link between the for-profit } \\
\text { intermediary entity and numerous players for which it carries } \\
\text { out diverse bridging roles. The study findings indicate that } \\
\text { whereas innovation intermediation remains beneficial, } \\
\text { misunderstandings may emerge concerning the innovation } \\
\text { intermediary's management framework, modes of revenue } \\
\text { generation, and various activities it performs. To minimize such } \\
\text { challenges, the authors recommend the demarcation of the } \\
\text { intermediary role to avoid competition with other financiers } \\
\text { of R\&D or knowledge-intensive business services. Equally, } \\
\text { funding of innovation intermediaries should be between } \\
\text { the public and private sectors. Region: Netherlands; Study: } \\
\text { quantitative; Period: } 2005 \text {. }\end{array}$ \\
\hline Biotechnology & $\begin{array}{l}\text { Toole and } \\
\text { Czarnitzki } \\
(2007)\end{array}$ & $\begin{array}{l}\text { The survey interrogates the Small Business Innovation Research } \\
\text { (SBIR) program as a policy facilitating entrepreneurship in } \\
\text { institutions of higher learning. The findings demonstrate } \\
\text { that the program is commercialization avenue by biomedical } \\
\text { academic researchers. Equally, the SBIR firms having scientists } \\
\text { are significantly better in terms of performance as compared } \\
\text { to other SBIR firms; more so on follow-up venture capital } \\
\text { financing, SBIR project completion, and patenting. Region: US; } \\
\text { Study: quantitative; Period: } 1972-1996 \text {. }\end{array}$ \\
\hline
\end{tabular}




\begin{tabular}{|c|c|c|}
\hline Theme & Study & Summary of the Study \\
\hline \multirow[t]{3}{*}{ Life Science } & $\begin{array}{l}\text { Bar-Shalom and } \\
\text { Cook-Deegan } \\
(2002)\end{array}$ & $\begin{array}{l}\text { The case study highlights the existing link between the } \\
\text { utilization of publicly funded research and academia- } \\
\text { positioned intellectual property. The study explains how } \\
\text { to patent legislation might or might not have a different } \\
\text { outcome in the medical sector when compared to other highly } \\
\text { technological areas. For example, medical innovations tend to } \\
\text { be subjected to more scrutiny from both moral and political } \\
\text { perspectives, unlike other non-medical sectors. Region: United } \\
\text { States; Study: qualitative. }\end{array}$ \\
\hline & $\begin{array}{l}\text { Lazonick and } \\
\text { Tulum (2011) }\end{array}$ & $\begin{array}{l}\text { The case study offers an answer to the "Pisano puzzle," } \\
\text { providing a base for investigating the industrial and } \\
\text { institutional environments under which the development } \\
\text { of the biopharmaceutical (BP) industry can be sustainable. } \\
\text { One component of the solution relates to the readiness of } \\
\text { the investors at the stock markets to soak in the initial public } \\
\text { offerings of a BP project yet to generate a commercial product } \\
\text { with the probability of never do so. The other component of } \\
\text { the solution is on the knowledge base tapped by BP firms to } \\
\text { develop products, to a large extent, this tends to come from } \\
\text { government financing and expenditure than from business } \\
\text { financing. Region: United States; Study: qualitative; Period; } \\
\text { 1983-2009. }\end{array}$ \\
\hline & $\begin{array}{l}\text { Goldfarb and } \\
\text { Henrekson } \\
(2003)\end{array}$ & $\begin{array}{l}\text { The comparative study examines the question of what national } \\
\text { policies are suitable for enhancing the commercialization of } \\
\text { academia-created knowledge. The findings point to laggard } \\
\text { levels of commercialization of university-generated research } \\
\text { output. The authors attribute this partly to the top-down style } \\
\text { of Swedish policies targeting commercialization of innovations } \\
\text { and academic surrounding that demotivates academicians } \\
\text { from actively engaging in the marketing of their results. On } \\
\text { the contrary, in the United States, institutional context is } \\
\text { defined by competition between universities and researchers } \\
\text { for research funding. The competition, in turn, leads to higher } \\
\text { academic flexibility, increased interaction with the industry, } \\
\text { especially with new firms. Region: Sweden and the United } \\
\text { States; Study: qualitative. }\end{array}$ \\
\hline
\end{tabular}

\section{CONCLUSION}

The authors performed a bibliographic review of published literature on innovation, funding, and policy from a business point of view. The survey examined documents published between 1990 and February 2019 extracted from the Web of Science core collection. A total of 437 articles were retrieved and went through various staged before settling on 32 publications. The analysis of retrieved documents focused on the journal of publication, articles per year, affiliations (publications) per country, co-authorship collaborations of the university, and the main themes of the reviewed studies. Still, the study outlines the citations received by each of the 32 selected publications and their summaries. The summaries grouped in themes have shown areas 
that have received more or less attention from researchers. The number of papers in the field has been growing over the years owing to reasons outlined earlier. Generally, countries engaged in higher levels of innovation had higher authoring. Interestingly, few studies on the subject matter were authored in emerging economies such as Africa and Asia, other than China and Taiwan, but to mention a few. The situation is the same for countries in the Middle East. Likewise, most of the collaborative studies are from institutions in the United States and European countries, while other regions lag. Equally, most of the reviewed studies focused on short periods of 5 years and below, probably due to rapid changes innovations. Finally, a case study was the preferred research approach for most authors, followed by comparative studies and the least being experimental; this is not to say there are no other study designs. Therefore, these could be opportunities for future studies.

Limitation, the authors appreciate that reviewing articles by the use of bibliographic techniques is not a substitute for the traditional comprehensive reading approach but rather a compliment. Thus, the method could be a limitation in itself. Moreover, the study used data retrieved from one database, whereas there are other well-established ones. The authors may have been subjective in their omission of articles in languages other than English. Still, it may not have been possible to present all the articles extensively, thus a summary of selected publications. Nonetheless, the findings show a picture of the present state of authoring on innovation, funding, and policy.

\section{Acknowledgment}

The authors express gratitude to the anonymous reviewers for their valuable suggestions and inputs.

\section{Reference}

Aaboen, L. (2009). Explaining incubators using a firm analogy. Technovation, 29(10), 657-670. https://doi.org/10.1016/j.technovation.2009.04.007

Afcha, S., \& León López, G. (2014). Public funding of R\&D and its effect on the composition of business R\&D expenditure. BRQ Business Research Quarterly, 17(1), 22-30. https://doi.org/10.1016/j.cede.2013.01.001

Aksoy, H. (2017). How do innovation culture, marketing innovation, and product innovation affect the market performance of small and mediumsized enterprises (SMEs). Technology in Society, 51, 133-141. https:// doi.org/10.1016/j.techsoc.2017.08.005

Aliasghar, O., Rose, E. L., \& Chetty, S. (2019). Where to search for process innovations? The mediating role of absorptive capacity and its impact 
on process innovation. Industrial Marketing Management, 82, 199-212. https://doi.org/10.1016/j.indmarman.2019.01.014

Antonioli, D., Marzucchi, A., \& Montresor, S. (2014). Regional innovation policy and innovative behavior: Looking for additional effects. European Planning Studies, 22(1), 64-83. https://doi.org/10.1080/09654313.2012.722977

Anzola-Román, P., Bayona-Sáez, C., \& García-Marco, T. (2018). Organizational innovation, internal R\&D, and externally sourced innovation practices: Effects on technological innovation outcomes. Journal of Business Research, 91, 233-247. https://doi.org/10.1016/j.jbusres.2018.06.014

Appelbaum, R. P., Gebbie, M. A., Han, X., Stocking, G., \& Kay, L. (2016). Will China's quest for indigenous innovation succeed? Some lessons from nanotechnology. Technology in Society, 46, 149-163. https://doi. org/10.1016/j.techsoc.2016.03.004

Archibugi, D., \& Filippetti, A. (2018). The retreat of public research and its adverse consequences on innovation. Technological Forecasting and Social Change, 127, 97-111. https://doi.org/10.1016/j.techfore.2017.05.022

Arundel, A., Bloch, C., \& Ferguson, B. (2019). Advancing innovation in the public sector: Aligning innovation measurement with policy goals. Research Policy, 48(3), 789-798. https://doi.org/10.1016/j.respol.2018.12.001

Azar, G., \& Ciabuschi, F. (2017). Organizational innovation, technological innovation, and export performance: The effects of innovation radicalness and extensiveness. International Business Review, 26(2), 324-336. https://doi.org/10.1016/j.ibusrev.2016.09.002

Bagchi-Sen, S., \& Scully, J. L. (2004). The Canadian environment for innovation and business development in the biotechnology industry: A firmlevel analysis. European Planning Studies, 12(7), 961-983. https://doi. org/10.1080/0965431042000267867

Baglieri, D., Baldi, F., \& Tucci, C. L. (2018). University technology transfer office business models: One size does not fit all. Technovation, 76, 51-63. https://doi.org/10.1016/j.technovation.2018.05.003

Baldock, R. (2015). An assessment of the business impacts of the UK's Enterprise Capital Funds. Environment and Planning C: Government and Policy, 34(8), 1556-1581. https://doi.org/10.1177/0263774X15625995

Bar-Shalom, A., \& Cook-Deegan, R. (2002). Patents and innovation in cancer therapeutics: Lessons from CellPro. The Milbank Quarterly, 80(4), 637676. https://doi.org/10.1111/1468-0009.00027

Bearse, P. M., \& Link, A. N. (2010). Economic implications of raising the threshold funding limits on US Small Business Innovation Research awards. Science and Public Policy, 37(10), 731-735. https://doi. org/10.3152/030234210×534896

Begonja, M., Čićek, F., Balboni, B., \& Gerbin, A. (2016). Innovation and business performance determinants of SMEs in the Adriatic region that introduced social innovation. Economic Research-Ekonomska Istrazivanja, 29(1), 1136-1149. https://doi.org/10.1080/1331677X.2016.1213651 
Bengtsson, L. (2017). A comparison of university technology transfer offices' commercialization strategies in the Scandinavian countries. Science and Public Policy, 44(4), 565-577. https://doi.org/10.1093/scipol/scw086

Bogers, M., Chesbrough, H., \& Moedas, C. (2018). Open innovation: Research, practices, and policies. California Management Review, 60(2), 5-16. https://doi.org/10.1177/0008125617745086

Bointner, R., Pezzutto, S., Grilli, G., \& Sparber, W. (2016). Financing innovations for the renewable energy transition in Europe. Energies, 9(12), 990. https://doi.org/10.3390/en9120990

Borrás, S., \& Laatsit, M. (2019). Towards system-oriented innovation policy evaluation? Evidence from EU28 member states. Research Policy, 48(1), 312-321. https://doi.org/10.1016/j.respol.2018.08.020

Bozeman, B., Fay, D., \& Slade, C. P. (2013). Research collaboration in universities and academic entrepreneurship: The-state-of-the-art. The Journal of Technology Transfer, 38(1), 1-67. https://doi.org/10.1007/ s10961-012-9281-8

Brav, A., Jiang, W., Ma, S., \& Tian, X. (2018). How does hedge fund activism reshape corporate innovation? Journal of Financial Economics, 130(2), 237-264. https://doi.org/10.1016/j.jfineco.2018.06.012

Breznitz, D., \& Ornston, D. (2018). The politics of partial success: Fostering innovation in innovation policy in an era of heightened public scrutiny. SocioEconomic Review, 16(4), 721-741. https://doi.org/10.1093/ser/mww018

Brown, E., Campbell, B., Cloke, J., To, L. S., Turner, B., \& Wray, A. (2018). Low carbon energy and international development: From research impact to policymaking. Contemporary Social Science, 13(1), 112-127. https://doi. org/10.1080/21582041.2017.1417627

Bumpus, A. G. (2015). Firm responses to a carbon price: Corporate decision making under British Columbia's carbon tax. Climate Policy, 15(4), 475493. https://doi.org/10.1080/14693062.2014.937389

Busom, I., Corchuelo, B., \& Martínez-Ros, E. (2014). Tax incentives... or subsidies for business R\&D? Small Business Economics, 43(3), 571-596. https://doi.org/10.1007/s11187-014-9569-1

Calo, A. (2018). How knowledge deficit interventions fail to resolve beginning farmer challenges. Agriculture and Human Values, 35(2), 367-381. https://doi.org/10.1007/s10460-017-9832-6

Campos, F., Coville, A., Fernandes, A. M., Goldstein, M., \& McKenzie, D. (2014). Learning from the experiments that never happened: Lessons from trying to conduct randomized evaluations of matching grant programs in Africa. Journal of the Japanese and International Economies, 33, 4-24. https://doi.org/10.1016/j.jjie.2013.12.007

Cantner, U., \& Kösters, S. (2012). Picking the winner? Empirical evidence on the targeting of R\&D subsidies to start-ups. Small Business Economics, 39(4), 921-936. https://doi.org/10.1007/s11187-011-9340-9

Catulli, M., \& Fryer, E. (2012). Information and communication technologyenabled low carbon technologies: A new subsector of the economy? 
Journal of Industrial Ecology, 16(3), 296-301. https://doi.org/10.1111/ j.1530-9290.2011.00452.x

Chakma, J., Masum, H., \& Singer, P. A. (2010). Can incubators work in Africa? Acorn Technologies and the entrepreneur-centric model. BMC International Health and Human Rights, 10(1), S7. https://doi. org/10.1186/1472-698X-10-S1-S7

Chang, H.-C., \& Tsai, C.-L. (2016). Evaluation of critical factors for the regional innovation system within the HsinChu science-based park. Kybernetes, 45(4), 699-716. https://doi.org/10.1108/K-02-2015-0059

Chen, J. Y., Dimitrov, S., \& Pun, H. (2019). The impact of government subsidy on supply Chains' sustainability innovation. Omega, 86, 42-58. https:// doi.org/10.1016/j.omega.2018.06.012

Chen, M. Y. (2011). Predicting corporate financial distress based on the integration of decision tree classification and logistic regression. Expert Systems with Applications, 38(9), 11261-11272. https://doi. org/10.1016/j.eswa.2011.02.173

Chen, Yi., Fei, Tang., Tie-Gang, L. I., Jiu-Ming, H. E., Abliz, Z., Li-Tao, L. I. U., \& Xiao-Hao, W. A. N. G. (2014). Application of factor analysis in imaging mass spectrometric data analysis. Chinese Journal of Analytical Chemistry, 42(8), 1099-1103. https://doi.org/10.1016/S1872-2040(14)60757-X

Chirambo, D. (2018). Towards the achievement of SDG 7 in sub-Saharan Africa: Creating synergies between Power Africa, Sustainable Energy for All and climate finance in-order to achieve universal energy access before 2030. Renewable and Sustainable Energy Reviews, 94, 600-608. https://doi.org/10.1016/j.rser.2018.06.025

Choi, S. (2012). Core-periphery, new clusters, or rising stars?: International scientific collaboration among "advanced" countries in the era of globalization. Scientometrics, 90(1), 25-41. https://doi.org/10.1007/ s11192-011-0509-4

Ciocanel, A. B., \& Pavelescu, F. M. (2015). Innovation and Competitiveness in the European Context. Procedia Economics and Finance, 32(15), 728737. https://doi.org/10.1016/s2212-5671(15)01455-0

Ciulli, F., \& Kolk, A. (2019). Incumbents and business model innovation for the sharing economy: Implications for sustainability. Journal of Cleaner Production, 214, 995-1010. https://doi.org/10.1016/j. jclepro.2018.12.295

Clarysse, B., Wright, M., Bruneel, J., \& Mahajan, A. (2014). Creating value in ecosystems: Crossing the chasm between knowledge and business ecosystems. Research Policy, 43(7), 1164-1176. https://doi. org/10.1016/j.respol.2014.04.014

Collewaert, V., Manigart, S., \& Aernoudt, R. (2010). Assessment of government funding of business angel networks in Flanders. Regional Studies, 44(1), 119-130. https://doi.org/10.1080/00343400802070860

Concilio, G., Molinari, F., \& Morelli, N. (2017, May). Empowering citizens with open data by urban hackathons. In 2017 Conference for E-Democracy 
and Open Government (CeDEM) (pp. 125-134). IEEE. https://doi. org/10.1109/CeDEM.2017.28

Cooke, P. (2004). Life sciences clusters and regional science policy. Urban Studies, 41(5-6), 1113-1131. https://doi.org/10.1080/00420980410001675814

Costa, S., Laureano, L. M. S., \& Laureano, R. M. S. (2014). The debt maturity of Portuguese SMEs: The aftermath of the 2008 financial crisis. Procedia Social and Behavioral Sciences, 150, 172-181. https://doi.org/10.1016/j. sbspro.2014.09.024

Cozzarin, B. P. (2008). Data and the measurement of R\&D program impacts. Evaluation and Program Planning, 31(3), 284-298. https://doi. org/10.1016/j.evalprogplan.2008.03.004

Crudu, R. (2019). The role of innovative entrepreneurship in the economic development of EU member countries. Journal of Entrepreneurship, Management and Innovation, 15(1), 35-60. https://doi. org/10.7341/20191512

Cumming, D. J., \& Fischer, E. (2012). Publicly funded business advisory services and entrepreneurial outcomes. Research Policy, 41(2), 467-481. https://doi.org/10.1016/j.respol.2011.09.004

Cumming, D., Johan, S., \& Zhang, M. (2014). The economic impact of entrepreneurship: Comparing international datasets. Corporate Governance: An International Review, 22(2), 162-178. https://doi. org/10.1111/corg.12058

Czarnitzki, D., \& Lopes-Bento, C. (2014). Innovation subsidies: Does the funding source matter for innovation intensity and performance? Empirical evidence from Germany. Industry and Innovation, 21(5), 380409. https://doi.org/10.1080/13662716.2014.973246

Das, B., Hui, X., \& Sha, S. J. (2018). Investment policies that support SME selfdevelopment. Human Systems Management, 37(1), 15-25. https://doi. org/10.3233/HSM-17131

De Laurentis, C. (2012). Renewable energy innovation and governance in Wales: A regional innovation system approach. European Planning Studies, 20(12), 1975-1996. https://doi.org/10.1080/09654313.2012.665041

De Lucia, C., Balena, P., Stufano Melone, M. R., \& Borri, D. (2016). Policy, entrepreneurship, creativity, and sustainability: The case of 'Principi Attivi' ('Active Ingredients') in the Apulia Region (Southern Italy). Journal of Cleaner Production, 135, 1461-1473. https://doi.org/10.1016/j. jclepro.2016.06.068

Diéguez-Soto, J., Garrido-Moreno, A., \& Manzaneque, M. (2018). Unraveling the link between process innovation inputs and outputs: The moderating role of family management. Journal of Family Business Strategy, 9(2), 114-127. https://doi.org/10.1016/j.jfbs.2017.11.007

Dimitrova, R. (2013). Growth in the intersection of eHealth and active and healthy aging. Technology and Health Care, 21(2), 169-172. https://doi. org/10.3233/THC-130727 
Distanont, A., \& Khongmalai, O. (2018). The role of innovation in creating a competitive advantage. Kasetsart Journal of Social Sciences, 1-7. https://doi.org/10.1016/j.kjss.2018.07.009

Divisekera, S., \& Nguyen, V. K. (2018). Determinants of innovation in tourism evidence from Australia. Tourism Management, 67, 157-167. https:// doi.org/10.1016/j.tourman.2018.01.010

Dodescu, A., \& Chirilă, L. F. (2013). Regional innovation governance in the context of European integration and multi-level governance challenges. A case study of North-West region of Romania. Procedia Economics and Finance, 3(12), 1177-1184. https://doi.org/10.1016/s22125671(12)00293-6

Domingo, A. M., \& Soriano, R. (2014). The level of innovation among young innovative companies: The impacts of knowledge-intensive services use, firm characteristics, and the entrepreneur attributes. Service Business, 8(51), 51-63. https://doi.org/10.1007/s11628-013-0186-x

Driver, C., \& Muñoz-Bugarin, J. (2019). Financial constraints on investment: Effects of firm size and the financial crisis. Research in International Business and Finance, 47, 441-457. https://doi.org/10.1016/j. ribaf.2018.09.006

Dvouletý, O., Longo, M. C., Blažková, I., Lukeš, M., \& Andera, M. (2018). Are publicly funded Czech incubators effective? The comparison of the performance of supported and non-supported firms. European Journal of Innovation Management, 21(4), 543-563. https://doi.org/10.1108/ EJIM-02-2018-0043

Dziallas, M., \& Blind, K. (2019). Innovation indicators throughout the innovation process: An extensive literature analysis. Technovation, 80, 3-29. https://doi.org/10.1016/j.technovation.2018.05.005

Džupka, P., Klasová, S., \& Kováč, V. (2016). Analysis of innovative start-up companies - Case of Košice region. Quality Innovation Prosperity, 20(1), 40-56. https://doi.org/10.12776/QIP.V20I1.641

Edoho, F. M. (2016). Entrepreneurship paradigm in the new millennium. Journal of Entrepreneurship in Emerging Economies, 8(2), 279-294. https://doi.org/10.1108/jeee-08-2015-0043

Edwards-Schachter, M. (2018). The nature and variety of innovation. International Journal of Innovation Studies, 2(2), 65-79. https://doi. org/10.1016/j.ijis.2018.08.004

Elnasri, A., \& Fox, K. J. (2017). The contribution of research and innovation to productivity. Journal of Productivity Analysis, 47(3), 291-308. https:// doi.org/10.1007/s11123-017-0503-9

Elston, J. A., \& Audretsch, D. B. (2011). Financing the entrepreneurial decision: An empirical approach using experimental data on risk attitudes. Small Business Economics, 36(2), 209-222. https://doi.org/10.1007/s11187009-9210-x

Engel, D., Rothgang, M., \& Eckl, V. (2016). Systemic aspects of R\&D policy subsidies for R\&D collaborations and their effects on private R\&D. 
Industry and Innovation, 23(2), 206-222. https://doi.org/10.1080/1366 2716.2016.1146127

Etzkowitz, H., \& Etzkowitz, A. (2015). Europe of the future and the future of Europe: The innovation/austerity choice. Industry and Higher Education, 29(2), 83-88. https://doi.org/10.5367/ihe.2015.0250

Evens, R., \& Kaitin, K. (2015). The evolution of biotechnology and its impact on health care. Health Affairs, 34(2), 210-219. https://doi.org/10.1377/ hlthaff.2014.1023

Fernández-Sastre, J., \& Montalvo-Quizhpi, F. (2019). The effect of developing countries' innovation policies on firms' decisions to invest in R\&D. Technological Forecasting and Social Change, 143, 214-223. https://doi.org/10.1016/j.techfore.2019.02.006

Ferreira, F. A. (2018). Mapping the field of arts-based management: Bibliographic coupling and co-citation analyses. Journal of Business Research, 85, 348-357. https://doi.org/10.1016/j.jbusres.2017.03.026

Finardi, U. (2014). Scientific collaboration between BRICS countries. Scientometrics, 102(2), 1139-1166. https://doi.org/10.1007/s11192014-1490-5

Fiore, M., Silvestri, R., Contò, F., \& Pellegrini, G. (2017). Understanding the relationship between green approach and marketing innovations tools in the wine sector. Journal of Cleaner Production, 142, 4085-4091. https:// doi.org/10.1016/j.jclepro.2016.10.026

Fogg, H. (2012). Tracing the links between absorptive capacity, university knowledge exchange, and competitive advantage in SMEs. The International Journal of Entrepreneurship and Innovation, 13(1), 35-44. https://doi.org/10.5367/ijei.2012.0061

Frenkel, A., Shefer, D., \& Miller, M. (2008). Public versus private technological incubator programmes: Privatizing the technological incubators in Israel. European Planning Studies, 16(2), 189-210. https://doi. org/10.1080/09654310701814504

Fundeanu, D. D., \& Badele, C. S. (2014). The Impact of regional innovative clusters on competitiveness. Procedia - Social and Behavioral Sciences, 124, 405-414. https://doi.org/10.1016/j.sbspro.2014.02.502

Garfield, E. (2001). From Bibliographic Coupling to Co-citation Analysis via Algorithmic Historio-ibliography. Philadelphia: Drexel University.

Gault, F. (2018). Defining and measuring innovation in all sectors of the economy. Research Policy, 47(3), 617-622. https://doi.org/10.1016/j. respol.2018.01.007

Gava, O., Favilli, E., Bartolini, F., \& Brunori, G. (2017). Knowledge networks and their role in shaping the relations within the agricultural knowledge and innovation system in the agro energy sector. The case of biogas in Tuscany (Italy). Journal of Rural Studies, 56, 100-113. https://doi. org/10.1016/j.jrurstud.2017.09.009 
Geissdoerfer, M., Vladimirova, D., \& Evans, S. (2018). Sustainable business model innovation: A review. Journal of Cleaner Production, 198, 401416. https://doi.org/10.1016/j.jclepro.2018.06.240

Ghauri, P. N., \& Rao, P. M. (2009). Intellectual property, pharmaceutical MNEs, and the developing world. Journal of World Business, 44(2), 206-215. https://doi.org/10.1016/j.jwb.2008.05.008

Gill, D. E. (2015). Consolidating the gains. Venture Capital, 17(1-2), 43-58. https://doi.org/10.1080/13691066.2015.1021029

Gilmore, A., \& Comunian, R. (2016). Beyond the campus: Higher education, cultural policy, and the creative economy. International Journal of Cultural Policy, 22(1), 1-9. https://doi.org/10.1080/10286632.2015.11 01089

Goldfarb, B., \& Henrekson, M. (2003). Bottom-up versus top-down policies towards the commercialization of university intellectual property. Research Policy, 32(4), 639-658. https://doi.org/10.1016/S00487333(02)00034-3

Gorraiz, J., Reimann, R., \& Gumpenberger, C. (2012). Key factors and considerations in the assessment of international collaboration: A case study for Austria and six countries. Scientometrics, 91(2), 417-433. https://doi.org/10.1007/s11192-011-0579-3

Greenhalgh, T., Ovseiko, P. V., Fahy, N., Shaw, S., Kerr, P., Rushforth, A. D., ... Kiparoglou, V. (2017). Maximizing value from a United Kingdom Biomedical Research Centre: Study protocol. Health Research Policy and Systems, 15(1), 70. https://doi.org/10.1186/s12961-017-0237-1

Gupta, S., Malhotra, N. K., Czinkota, M., \& Foroudi, P. (2016). Marketing innovation: A consequence of competitiveness. Journal of Business Research, 69(12), 5671-5681. https://doi.org/10.1016/j. jbusres.2016.02.042

Gurzawska, A., Mäkinen, M., \& Brey, P. (2017). Implementation of Responsible Research and Innovation (RRI) practices in industry: Providing the right incentives. Sustainability, 9(10), 1759. https://doi.org/10.3390/ su9101759

Talab, A. H., Scholten, V., \& van Beers, C. (2018). The role of universities in inter-organizational knowledge collaborations. Journal of the Knowledge Economy, 1-21. https://doi.org/10.1007/s13132-018-0545-x

Hamelink, M., \& Opdenakker, R. (2019). How business model innovation affects firm performance in the energy storage market. Renewable Energy, 131, 120-127. https://doi.org/10.1016/j.renene.2018.07.051

Hannigan, T. R., Seidel, V. P., \& Yakis-Douglas, B. (2018). Product innovation rumors as forms of open innovation. Research Policy, 47(5), 953-964. https://doi.org/10.1016/j.respol.2018.02.018

Hartley, J., \& Montgomery, L. (2009). Creative industries come to China (MATE). Chinese Journal of Communication, 2(1), 1-12. https://doi. org/10.1080/17544750802638798 
Hauser, O. P., Linos, E., \& Rogers, T. (2017). Innovation with field experiments: Studying organizational behaviors in actual organizations. Research in Organizational Behavior, 37, 185-198. https://doi.org/10.1016/j. riob.2017.10.004

Heimonen, T. (2012). What are the factors that affect innovation in growing SMEs? European Journal of Innovation Management, 15(1), 122-144. https://doi.org/10.1108/14601061211192861

Hellström, T., \& Jacob, M. (2005). Taming unruly science and saving national competitiveness: Discourses on science by Sweden's strategic research bodies. Science Technology and Human Values, 30(4), 443-467. https:// doi.org/10.1177/0162243905276504

Hemphill, T. A. (2013). POLICY DEBATE: The Obama innovation strategy: How will it influence U.S business innovation and R \& D management? Innovation: Management, Policy, and Practice, 15(3), 260-270. https:// doi.org/10.5172/impp.2013.15.3.260

Henrekson, M., \& Sanandaji, T. (2018). Stock option taxation and venture capital activity: A cross-country study. Venture Capital, 20(1), 51-71. https://doi.org/10.1080/13691066.2017.1400159

Hermans, F., Geerling-Eiff, F., Potters, J., \& Klerkx, L. (2019). Publicprivate partnerships as systemic agricultural innovation policy instruments-Assessing their contribution to innovation system function dynamics. NJAS-Wageningen Journal of Life Sciences, 88, 76-95. https:// doi.org/10.1016/j.njas.2018.10.001

Heshmati, A. (2015). The effect of credit guarantees on SMEs' R\&D investments in Korea. Asian Journal of Technology Innovation, 23(3), 407-421. https://doi.org/10.1080/19761597.2015.1131955

Hjalager, A. M. (2009). Cultural tourism innovation systems - the Roskilde festival. Scandinavian Journal of Hospitality and Tourism, 9(2-3), 266287. https://doi.org/10.1080/15022250903034406

Holm, E. J. Van. (2015). Makerspaces and contributions to entrepreneurship. Procedia - Social and Behavioral Sciences, 195, 24-31. https://doi. org/10.1016/j.sbspro.2015.06.167

Hoppe, T., \& Sanders, P. T. M. (2014). Agricultural green gas demonstration projects in the Netherlands. A stakeholder analysis. Environmental Engineering and Management Journal, 13(12), 3083-3096. https://doi. org/10.30638/eemj.2014.347

Hunt, W., Birch, C., Vanclay, F., \& Coutts, J. (2014). Recommendations arising from an analysis of changes to the Australian agricultural research, development, and extension system. Food Policy, 44, 129-141. https:// doi.org/10.1016/j.foodpol.2013.11.007

Jaekel, M., Wallin, A., \& Isomursu, M. (2015). Guiding networked innovation projects towards commercial success - a case study of an EU innovation programme with implications for targeted open innovation. Journal of the Knowledge Economy, 6(3), 625-639. https://doi.org/10.1007/ s13132-015-0274-3 
Jarneving, B. (2007). Complete graphs and bibliographic coupling: A test of the applicability of bibliographic coupling for the identification of cognitive cores on the field level. Journal of Informetrics, 1(4), 338-356. https://doi.org/10.1016/j.joi.2007.08.001

Jordan, N. D., Lemken, T., \& Liedtke, C. (2014). Barriers to resource efficiency innovations and opportunities for smart regulations-the case of Germany. Environmental Policy and Governance, 24(5), 307-323. https://doi. org/10.1002/eet.1632

Jr., W. W. C., \& Paolucci, E. (2004). Commercial development of environmental technologies for the automotive industry towards a new model of technological innovation. International Journal of Technology Management, 21(5/6), 565. https://doi.org/10.1504/ijtm.2001.002935

Kahn, K. B. (2018). Understanding innovation. Business Horizons, 61(3), 453460. https://doi.org/10.1016/j.bushor.2018.01.011

Kalisz, D. E., \& Aluchna, M. (2012). Research and innovations redefined. Perspectives on European Union initiatives and strategic choices on Horizon 2020. European Integration Studies, (6), 140-149. https://doi. org/10.5755/j01.eis.0.6.1426

Kasa, S., \& Underthun, A. (2010). Navigation in new terrain with familiar maps: Masterminding socio-spatial equality through resource-oriented innovation policy. Environment and Planning A, 42(6), 1328-1345. https://doi.org/10.1068/a4226

Kenney, M., \& Patton, D. (2018). Sub-national technology policy and commerce: Evaluating the impacts of the California Institute for Regenerative Medicine. Journal of Technology Transfer, 43(1), 47-68. https://doi.org/10.1007/s10961-017-9580-1

Kessler, M. M. (1963). An experimental study of bibliographic coupling between technical papers. IEEE Transactions on Information Theory, 9(1), 49-51. https://doi.org/10.1109/TIT.1963.1057800

Kim, K. W. (2006). Measuring international research collaboration of peripheral countries: Taking the context into consideration. Scientometrics, 66(2), 231-240. https://doi.org/10.1007/s11192-006-0017-0

Kim, Y., Lim, H. J., \& Lee, S. J. (2014). Applying research collaboration as a new way of measuring research performance in Korean universities. Scientometrics, 99(1), 97-115. https://doi.org/10.1007/s11192-013-1095-4

Klerkx, L., \& Leeuwis, C. (2008). Balancing multiple interests: Embedding innovation intermediation in the agricultural knowledge infrastructure. Technovation, 28(6), 364-378. https://doi.org/10.1016/j.technovation.2007.05.005

Kolesnyk, M. Y. (2017). Analysis of innovation indicators of European countries and Ukraine. Marketing and Management of Innovations, (2), 172-181. https://doi.org/10.21272/mmi.2017.2-16

Kolk, A. (2015). The role of international business in clean technology transfer and development. Climate Policy, 15(1), 170-176. https://doi.org/10.10 80/14693062.2013.772357 
Kolympiris, C., Kalaitzandonakes, N., \& Miller, D. (2014). Public funds and local biotechnology firm creation. Research Policy, 43(1), 121-137. https:// doi.org/10.1016/j.respol.2013.07.012

Lanahan, L. (2016). Multilevel public funding for small business innovation: A review of US state SBIR match programs. Journal of Technology Transfer, 41(2), 220-249. https://doi.org/10.1007/s10961-015-9407-x

Lazonick, W., \& Tulum, Ö. (2011). US biopharmaceutical finance and the sustainability of the biotech business model. Research Policy, 40(9), 1170-1187. https://doi.org/10.1016/j.respol.2011.05.021

Lin, J. Y. (2017). Balancing industry collaboration and academic innovation: The contingent role of collaboration-specific attributes. Technological Forecasting and Social Change, 123, 216-228. https://doi.org/10.1016/j. techfore.2016.03.016

Lindberg, M., Danilda, I., \& Torstensson, B. M. (2012). Women resource centres-A creative knowledge environment of Quadruple Helix. Journal of the Knowledge Economy, 3(1), 36-52. https://doi.org/10.1007/ s13132-011-0053-8

Link, A. N., \& Scott, J. T. (2010). Government as an entrepreneur : Evaluating the commercialization success of SBIR. Research Policy, 39(5), 589-601. https://doi.org/10.1016/j.respol.2010.02.006

Link, A. N., \& Wright, M. (2015). On the failure of $\mathrm{R}$ and $\mathrm{D}$ projects. IEEE Transactions on Engineering Management, 62(4), 442-448. https://doi. org/10.1109/TEM.2015.2404873

Löfsten, H., \& Lindelöf, P. (2003). Determinants for an entrepreneurial milieu: Science Parks and business policy in growing firms. Technovation, 23(1), 51-64. https://doi.org/10.1016/S0166-4972(01)00086-4

Lopez-Berzosa, D., \& Gawer, A. (2014). Innovation policy within private collectives: Evidence on 3GPP's regulation mechanisms to facilitate collective innovation. Technovation, 34(12), 734-745. https://doi. org/10.1016/j.technovation.2014.07.005

Luukkonen, T., Deschryvere, M., \& Bertoni, F. (2013a). The value added by government venture capital funds compared with independent venture capital funds. Technovation, 33(4-5), 154-162. https://doi. org/10.1016/j.technovation.2012.11.007

Lynch, N., Lenihan, H., \& Hart, M. (2009). Developing a framework to evaluate business networks: The case of Ireland's industryled network initiative. Policy Studies, 30(2), 163-180. https://doi. org/10.1080/01442870902723683

Lynskey, M. J. (2004). Determinants of innovative activity in Japanese technology-based start-up firms. International Small Business Journal, 22(2), 159-196. https://doi.org/10.1177/0266242604041312

Makkonen, T., Williams, A. M., Weidenfeld, A., \& Kaisto, V. (2018). Cross-border knowledge transfer and innovation in the European neighborhood: Tourism cooperation at the Finnish-Russian border. Tourism Management, 68, 140-151. https://doi.org/10.1016/j.tourman.2018.03.008 
Malen, J., \& Marcus, A. A. (2017). Promoting clean energy technology entrepreneurship: The role of external context. Energy Policy, 102, 7-15. https://doi.org/10.1016/j.enpol.2016.11.045

Mamonov, S., \& Malaga, R. (2018). Success factors in Title III equity crowdfunding in the United States. Electronic Commerce Research and Applications, 27, 65-73. https://doi.org/10.1016/j.elerap.2017.12.001

McAdam, R., Miller, K., McAdam, M., \& Teague, S. (2012). The development of University Technology Transfer stakeholder relationships at a regional level: Lessons for the future. Technovation, 32(1), 57-67. https://doi. org/10.1016/j.technovation.2011.08.001

Meissner, D., Cervantes, M., \& Kratzer, J. (2018). Enhancing university-industry linkages potentials and limitations of government policies. International Journal of Technology Management, 78(1-2), 147-162. https://doi. org/10.1504/IJTM.2018.093944

Mendes, S., Serrasqueiro, Z., \& Nunes, P. M. (2014). Investment determinants of young and old Portuguese SMEs: A quantile approach. BRQ Business Research Quarterly, 17(4), 279-291. https://doi.org/10.1016/j. brq.2013.03.001

Minshall, T., Kouris, S., Mortara, L., Schmithausen, P., \& Weiss, D. (2014). Developing infrastructure to support open innovation: Case studies from the east of England. International Journal of Innovation and Technology Management, 11(01), 1440006. https://doi.org/10.1142/ s0219877014400069

Möldner, A. K., Garza-Reyes, J. A., \& Kumar, V. (2020). Exploring lean manufacturing practices' influence on process innovation performance. Journal of Business Research, 106, 233-249. https://doi. org/10.1016/j.jbusres.2018.09.002

Moreton, S. (2016). Rethinking 'knowledge exchange': New approaches to collaborative work in the arts and humanities. International Journal of Cultural Policy, 22(1), 100-115. https://doi.org/10.1080/10286632.201 5.1101081

Al-Mubaraki, H.M., Muhammad, A.H., \& Busler, M. (2015). Categories of incubator success: A case study of three New York incubator programmes. World Journal of Science, Technology and Sustainable Development, 12(1), 2-12. https://doi.org/10.1108/WJSTSD-06-2014-0006

Murray, G. C. (1998). A policy response to regional disparities in the supply of risk capital to new technology-based firms in the European Union: The European Seed Capital Fund Scheme. Regional Studies, 32(5), 405-419. https://doi.org/10.1080/00343409850116817

Muscio, A., \& Nardone, G. (2012). The determinants of university-industry collaboration in food science in Italy. Food Policy, 37(6), 710-718. https:// doi.org/10.1016/j.foodpol.2012.07.003

Nelson, R. R. (1995). Why should managers be thinking about technology policy? Strategic Management Journal, 16(8), 581-588. https://doi. org/10.1002/smj.4250160802 
North, D., Baldock, R., \& Ullah, F. (2013). Funding the growth of UK technologybased small firms since the financial crash: Are there breakages in the finance escalator? Venture Capital, 15(3), 237-260. https://doi.org/10.1 080/13691066.2013.804755

Olson, E., \& Young, A. T. (2016). Discretionary monetary policy, quantitative easing, and the decline in US labor share. Economics and Business Letters, 4(2), 63. https://doi.org/10.17811/ebl.4.2.2015.63-78

Ortiz-Villajos, J. M., \& Sotoca, S. (2018). Innovation and business survival: A long-term approach. Research Policy, 47(8), 1418-1436. https://doi. org/10.1016/j.respol.2018.04.019

Owen, R., Brennan, G., \& Lyon, F. (2018). Enabling investment for the transition to a low carbon economy: government policy to finance earlystage green innovation. Current Opinion in Environmental Sustainability, 31, 137-145. https://doi.org/10.1016/j.cosust.2018.03.004

Padilla-Ospina, A. M., Medina-Vásquez, J. E., \& Rivera-Godoy, J. A. (2018). Financing innovation: A bibliometric analysis of the field. Journal of Business and Finance Librarianship, 23(1), 63-102. https://doi.org/10.10 80/08963568.2018.1448678

Parvizi, N., \& Parvizi, S. (2017). New health technologies: A UK perspective comment on "Providing Value to New Health Technology: The Early Contribution of Entrepreneurs, Investors, and Regulatory Agencies." International Journal of Health Policy and Management, 6(12), 721-722. https://doi.org/10.15171/ijhpm.2017.59

Paunov, C. (2012). The global crisis and firms' investments in innovation. Research Policy, 41(1), 24-35. https://doi.org/10.1016/j. respol.2011.07.007

Pavitt, K. (1998). The inevitable limits of EU R\&D funding. Research Policy, 27(6), 559-568. https://doi.org/10.1016/S0048-7333(98)00056-0

Pelikánová, R. M. (2019). R\&D expenditure and innovation in the EU and selected member states. Journal of Entrepreneurship, Management, and Innovation, 15(1), 13-34. https://doi.org/ 10.7341/20191511.

Perampaladas, K., Masum, H., Kapoor, A., Shah, R., Daar, A. S., \& Singer, P. A. (2010). The road to commercialization in Africa: Lessons from developing the sickle-cell drug Niprisan. BMC International Health and Human Rights, 10(1), S11. https://doi.org/10.1186/1472-698X-10-S1-S11

Pergelova, A., \& Angulo-Ruiz, F. (2014). The impact of government financial support on the performance of new firms: The role of competitive advantage as an intermediate outcome. Entrepreneurship and Regional Development, 26(9-10), 663-705. https://doi.org/10.1080/08985626.2014.980757

Petrescu, A. S. (2009). Science and technology for economic growth. New insights from when the data contradicts desktop models. Review of Policy Research, 26(6), 839-880. https://doi.org/10.1111/j.15411338.2009.00420.x

Pieroni, M. P. P., McAloone, T. C., \& Pigosso, D. C. A. (2019). Business model innovation for circular economy and sustainability: A review of 
approaches. Journal of Cleaner Production, 215, 198-216. https://doi. org/10.1016/j.jclepro.2019.01.036

Pike, M. A. (2010). Transaction and transformation at trinity: Private sponsorship, core values, and Christian ethos at England's most improved academy. Oxford Review of Education, 36(6), 749-765. https://doi.org/1 $0.1080 / 03054985.2010 .510625$

Pollman, E., \& Barry, J. M. (2016). Regulatory entrepreneurship. Southern California Law Review, 90, 383. https://doi.org/10.2139/ssrn.2741987

Prajogo, D. I. (2016). The strategic fit between innovation strategies and the business environment in delivering business performance. International Journal of Production Economics, 171, 241-249. https:// doi.org/10.1016/j.ijpe.2015.07.037

Matlay, H., Rae, D., Martin, L., Antcliff, V., \& Hannon, P. (2012). Enterprise and entrepreneurship in English higher education: 2010 and beyond. Journal of Small Business and Enterprise Development. https:// doi.org/10.1177/0266242607080656

Ratten, V., Ferreira, J., \& Fernandes, C. (2016). Entrepreneurial and network knowledge in emerging economies. Review of International Business and Strategy, 26(3), 392-409. https://doi.org/10.1108/ribs-11-2015-0076

Hrdy, C. A. (2015). Commercialization Awards. Wis. L. REv., 13. https://www. law.berkeley.edu/files/Hrdy_Camilla_IPSC_paper_2014.pdf

Reficco, E., \& Gutiérrez, R. (2016). Organizational ambidexterity and the elusive quest for successful implementation of BoP ventures. Organization and Environment, 29(4), 461-485. https://doi. org/10.1177/1086026616643136

Rizos, V., Behrens, A., Van der Gaast, W., Hofman, E., loannou, A., Kafyeke, T., ... \& Topi, C. (2016). Implementation of circular economy business models by small and medium-sized enterprises (SMEs): Barriers and enablers. Sustainability, 8(11), 1212. https://doi.org/10.3390/su8111212

Rosli, A., \& Rossi, F. (2016). Third-mission policy goals and incentives from performance-based funding: Are they aligned? Research Evaluation, 25(4), 427-441. https://doi.org/10.1093/reseval/rvw012

Rószkiewicz, M. (2014). On the influence of science funding policies on business sector R\&D activity. Equilibrium. Quarterly Journal of Economics and Economic Policy, 9(3), 9-26. https://www.ceeol.com/search/articledetail?id=50143

Jefferson, G.H.,Huamao, B., Xiaojing,G., \&Xiaoyun,Y.(2006). R\&Dperformancein the Chinese industry. Economics of Innovation and New Technology, 15(45), 345-366. https://doi.org/10.1080/10438590500512851

Rubach, S. (2013). Collaborative regional innovation initiatives: A booster for local company innovation processes? Systemic Practice and Action Research, 26(1), 3-21. https://doi.org/10.1007/s11213-012-9270-8

Sá, C. M., Kretz, A., \& Sigurdson, K. (2013). Accountability, performance assessment, and evaluation: Policy pressures and responses from 
research councils. Research Evaluation, 22(2), 105-117. https://doi. org/10.1093/reseval/rvs041

Sabri, Y., Micheli, G. J., \& Nuur, C. (2018). Exploring the impact of innovation implementation on supply chain configuration. Journal of Engineering and Technology Management, 49, 60-75. https://doi.org/10.1016/j. jengtecman.2018.06.001

Samford, S., Warrian, P., \& Goracinova, E. (2017). Public and private goods in the development of additive manufacturing capacity. Business and Politics, 19(03), 482-509. https://doi.org/10.1017/bap.2017.4

Seppo, M., Rõigas, K., \& Varblane, U. (2014). Governmental support measures for university-industry cooperation-comparative view in Europe. Journal of the Knowledge Economy, 5(2), 388-408. https://doi.org/10.1007/ s13132-014-0193-8

Shapira, P., \& Wang, J. (2009). From lab to market? Strategies and issues in the commercialization of nanotechnology in China. Asian Business and Management, 8(4), 461-489. https://doi.org/10.1057/abm.2009.15

Sisko Patana, A., Pihlajamaa, M., Polvinen, K., Kanto, L., \& Carleton, T. (2013). Inducement and blocking mechanisms in the Finnish life sciences innovation system. Foresight, 15(6), 428-445. https://doi.org/10.1108/ FS-10-2012-0081

Sjøvaag, H., \& Krumsvik, A. H. (2017). In search of journalism funding. Journalism Practice, 12(9), 1201-1219. https://doi.org/10.1080/175127 86.2017.1370972

Small, H. G., \& Koenig, M. E. (1977). Journal clustering using a bibliographic coupling method. Information Processing \& Management, 13(5), 277288. https://doi.org/10.1016/0306-4573(77)90017-6

Sofouli, E., \& Vonortas, $\mathbb{A}$. N. S. (2007). S \& T Parks and business incubators in middle-sized countries: The case of Greece, 525-544. https://doi. org/10.1007/s10961-005-6031-1

Stawasz, E. (2019). Factors that shape the competitiveness of small innovative companies operating in international markets with a particular focus on business advice, Journal of Entrepreneurship, Management and Innovation, 15(1), 61-82. https://doi.org/10.7341/20191513

Strähle, M., Raats, M. M., Neresini, F., Newton, R., Ortega, S., Coutinho, D., ... de Boer, A. (2016). The framing of innovation among European research funding actors: Assessing the potential for 'responsible research and innovation' in the food and health domain. Food Policy, 62, 78-87. https://doi.org/10.1016/j.foodpol.2016.04.004

Tamásy, C. (2007). Rethinking technology-oriented business incubators: Developing a robust policy instrument for entrepreneurship, innovation, and regional development?. Growth and Change, 38(3), 460-473. https://doi.org/10.1111/j.1468-2257.2007.00379.x

Tan, L. M., Hock, E. L. P., \& Tang, C. F. (2018). Finance \& Economics Readings. https://doi.org/10.1007/978-981-10-8147-7 
Tang, M., Baskaran, A., Pancholi, J., \& Lu, Y. (2013). Technology business incubators in China and India: A comparative analysis. Journal of Global Information Technology Management, 16(2), 33-58. https://doi.org/10. 1080/1097198X.2013.10845635

Ton, G., Klerkx, L., de Grip, K., \& Rau, M. L. (2015). Innovation grants to smallholder farmers: Revisiting the key assumptions in the impact pathways. Food Policy, 51, 9-23. https://doi.org/10.1016/j. foodpol.2014.11.002

Toole, A. A., \& Czarnitzki, D. (2007). Biomedical academic entrepreneurship through the SBIR program. Journal of Economic Behavior \& Organization, 63(4), 716-738. https://doi.org/10.1016/j. jebo.2006.05.011

Tsuruta, D. (2019). Working capital management during the global financial crisis: Evidence from Japan. Japan and the World Economy, 49, 206-219. https://doi.org/10.1016/j.japwor.2019.01.002

Vence, X., \& Gunti, X. (2000). Determinants of the European Planning Studies, 8(1). The 'Low R\&D Trap,' 8(1) 29-42. https://doi.org/10.1080/096543100110910

Venturini, K., \& Verbano, C. (2017). Open innovation in the public sector: Resources and performance of research-based spin-offs. Business Process Management Journal, 23(6), 1337-1358. https://doi.org/10.1108/ BPMJ-10-2016-0208

Vickers, I., \& North, D. (2000). Regional technology initiatives: Some insights from the English regions. European Planning Studies, 8(3), 301-318. https://doi.org/10.1080/713666413

Walwyn, D., \& Cloete, L. (2016). Universities are becoming major players in the national system of innovation. South African Journal of Science, 112(7-8), 1-8. https://doi.org/10.17159/sajs.2016/20150358

Wang, Y., Hu, D., Li, W., Li, Y., \& Li, Q. (2015). Collaboration strategies and effects on university research: Evidence from Chinese universities. Scientometrics, 103(2), 725-749. https://doi.org/10.1007/s11192-015-1552-3

Wang, Y., Li, J., \& Furman, J. L. (2017). Firm performance and state innovation funding: Evidence from China's innofund program. Research Policy, 46(6), 1142-1161. https://doi.org/10.1016/j.respol.2017.05.001

Wang, Y., Wang, X., Chang, S., \& Kang, Y. (2019). Product innovation and process innovation in a dynamic Stackelberg game. Computers and Industrial Engineering, 130, 395-403. https://doi.org/10.1016/j.cie.2019.02.042

Weinberg, B. H. (1974). Bibliographic coupling: A review. Information Storage and Retrieval, 10(5-6), 189-196. https://doi.org/10.1016/00200271(74)90058-8

Welsh, D. H. B., Kaciak, E., Trimi, S., \& Mainardes, E. W. (2018). Women entrepreneurs and family firm heterogeneity: Evidence from an emerging economy. Group Decision and Negotiation, 27(3), 445-465. https://doi. org/10.1007/s10726-017-9544-8 
White, S., Gao, J., \& Zhang, W. (2005). Financing new ventures in China: System antecedents and institutionalization. Research Policy, 34(6), 894-913. https://doi.org/10.1016/j.respol.2005.04.002

Winskel, M., Radcliffe, J., Skea, J., \& Wang, X. (2014). Remaking the UK's energy technology innovation system: From the margins to the mainstream. Energy Policy, 68, 591-602. https://doi.org/10.1016/j.enpol.2014.01.009

Witten, K., Carroll, P., Calder-Dawe, O., Smith, M., Field, A., \& Hosking, J. (2018). Te Ara Mua-Future Streets: Knowledge exchange and the highs and lows of researcher-practitioner collaboration to design active travel infrastructure. Journal of Transport \& Health, 9, 34-44. https://doi. org/10.1016/j.jth.2018.03.001

Woolley, J. L. (2017). Origins and outcomes: The roles of spin-off founders and intellectual property in high-technology venture outcomes. Academy of Management Discoveries, 3(1), 64-90. https://doi.org/10.5465/amd.2014.0138

Wong, D. T., \& Ngai, E. W. (2019). A critical review of supply chain innovation research (1999-2016). Industrial Marketing Management. 1-30. https:// doi.org/10.1016/j.indmarman.2019.01.017

Wonglimpiyarat, J. (2016). Government policies towards Israel's high-tech powerhouse. Technovation, 52, 18-27. https://doi.org/10.1016/j. technovation.2016.02.001

Wonglimpiyarat, J. (2018). Challenges and dynamics of FinTech crowdfunding: An innovation system approach. Journal of High Technology Management Research, 29(1), 98-108. https://doi.org/10.1016/j.hitech.2018.04.009

Wu, Y., Popp, D., \& Bretschneider, S. (2007). The effects of innovation policies on business R\&D: A cross-national empirical study. Economics of Innovation and New Technology, 16(4), 237-253. https://doi. org/10.1080/10438590600661939

Yan, M. R., Chien, K. M., Hong, L. Y., \& Yang, T. N. (2018). Evaluating the collaborative ecosystem for an innovation-driven economy: A systems analysis and case study of science parks. Sustainability, 10(3), 887. https://doi.org/10.3390/su10030887

Zanotto, S. R., Haeffner, C., \& Guimarães, J. A. (2016). Unbalanced international collaboration affects adversely the usefulness of countries' scientific output as well as their technological and social impact. Scientometrics, 109(3), 1789-1814. https://doi.org/10.1007/s11192-016-2126-8

Zhang, J., Xie, H., Li, H., Timothy, R., Pu, S., Deng, Q., \& Jin, W. (2018). An integrated framework of growth management for the identification of service innovation levels and priorities. Sustainability, 10(9), 3319. https://doi.org/10.3390/su10093319

Zhao, J., Wu, G., Xi, X., Na, Q., \& Liu, W. (2018). How collaborative innovation system in a knowledge-intensive competitive alliance evolves? An empirical study on China, Korea, and Germany. Technological Forecasting and Social Change, 137, 128-146. https://doi.org/10.1016/j. techfore.2018.07.001 


\title{
Other sources
}

[1] https://www.mckinsey.com/business-functions/strategy-and-corporatefinance/how-we-help-clients/growth-and-innovation

[2] https://www2.deloitte.com/content/dam/Deloitte/ie/Images/promo_ images/IE_C_HCtrends2017.pdf

[3] https://www.innosight.com/insight/creative-destruction/

[4] https://www.businessinsider.com/booz-and-cos-innovation-study-2011-10

\begin{abstract}
Abstrakt
W ostatniej dekadzie, badania empiryczne, koncentrujqce się na innowacjach zwiqzanych z biznesem, finansowaniu działań innowacyjnych oraz polityce (implikacje), stale rosły. Nie podjęto jednak jeszcze wystarczajq̨cych starań, aby zbadać istniejqcq literaturę na ten temat. Aby wypełnić tę lukę, niniejsze badanie ma na celu zsyntetyzowanie i zmapowanie istniejqcych badań empirycznych na temat innowacji biznesowych, finansowania i ram polityki opublikowanych między 1990 a lutym 2019 r. Analizę bibliograficznq odpowiednich artykułów uzyskanych z Web of Science Core Collection przeprowadzono za pomocq Vosviewer. Wyniki bibliometryczne pokazujq wybitne publikacje, autorytetów i badaczy, dominujqce instytucje szkolnictwa wyższego i kraje. Wybrane artykuły poddano analizie treści, zapewniajqc streszczenie publikacji, przyjętq metodologię, kraj i okres badań. Artykuły zostały podzielone na różne tematy w oparciu o ukierunkowanie badania, wskazujqc w ten sposób obszary, które zyskały mniej lub bardziej uwagę naukowq. Zidentyfikowane luki zarówno w analizie bibliograficznej, jak i treściowej oferujq przyszłe możliwości badawcze w różnych aspektach dotyczq̨cych innowacji biznesowych, sposobu finansowania i powiqzanych kwestii politycznych.
\end{abstract}

Słowa kluczowe: innowacje biznesowe, finansowanie, ramy polityki, bibliometria, analiza cytowań, Scientometrics

\section{Biographical notes}

Edmund Mallinguh (a Ph.D. candidate) is a full-time researcher in the School of Economics and Social Science at Szent István University, Hungary. He holds advanced qualifications in finance, accounting, and entrepreneurship, with his research interests revolving around these three themes. He continues to publish and co-author articles in high-quality journals and presents at international conferences. His doctoral work aims at combining his background in finance and entrepreneurship, particularly innovation, with a focus on emerging economies.

Zoltan Zeman (Ph.D.) is the head of the Finance Department in the School of Economics and Social Science at Szent István University, Hungary. His areas of interest include, but are not limited to, financial control, regulation, internal control, business management, and stock markets. He has authored several 
publications and has attended some prestigious national and international academic and professional conferences. Besides, he sits on the boards of several private or government entities.

\section{Conflicts of interest}

The authors declare no conflict of interest.

\section{Citation (APA Style)}

Mallinguh, E.,\& Zoltan, Z. (2020). Map of the existing research on business innovation, funding, and policy framework. Journal of Entrepreneurship, Management and Innovation, 16(2), 161-202. https://doi.org/10.7341/20201626 